\title{
Transformation of a Large Ancient Oil Reservoir to a Dry Gas Reservoir: A Case Study of the Kela-2 Gas Field in the Kuqa Foreland Basin, NW China
}

\author{
Xuesong Lu $\mathbb{D}^{1},{ }^{1,2}$ Zhichao Yu $\mathbb{D}^{1,2}$ Keyu Liu, ${ }^{3}$ Mengjun Zhao, ${ }^{1,2}$ Junjia Fan, ${ }^{1,2}$ \\ Xiaowen Guo, ${ }^{4}$ Qingong Zhuo, ${ }^{1,2}$ and Lili Gui ${ }^{1,2}$ \\ ${ }^{1}$ Research Institute of Petroleum Exploration \& Development, PetroChina, Beijing 100083, China \\ ${ }^{2}$ Key Laboratory of Basin Structure and Hydrocarbon Accumulation, CNPC, Beijing 100083, China \\ ${ }^{3}$ Faculty of Earth Sciences \& Technology, China University of Petroleum, Qingdao 266555, China \\ ${ }^{4}$ Key Laboratory of Tectonics and Petroleum Resources (China University of Geosciences), Ministry of Education, \\ Wuhan 430074, China
}

Correspondence should be addressed to Xuesong Lu; luxs@petrochina.com.cn

Received 11 December 2020; Accepted 17 December 2021; Published 11 February 2022

Academic Editor: Henrik Drake

Copyright (c) 2022 Xuesong Lu et al. This is an open access article distributed under the Creative Commons Attribution License, which permits unrestricted use, distribution, and reproduction in any medium, provided the original work is properly cited.

Various lines of evidence, including the occurrence of bitumen and fluid inclusions, show that oil charge once took place in the Kela-2 gas field, Kuqa foreland basin, Northwest China. However, the scale of the ancient oil reservoir remains unclear, as does the process by which the reservoir evolved into the present dry gas field. Here, using data from analyses of fluid inclusions, petrography, laser Raman spectroscopy, and quantitative fluorescence, the hydrocarbon accumulation history of the Kela-2 gas field is reconstructed. The results show that the gas field underwent three periods of hydrocarbon charging and one period of adjustment. The first oil charging occurred at about $12 \mathrm{Ma}$, as recorded by the first group of oil inclusions containing $0-8$ vol.\% gas with yellowish-brown fluorescence. The second charging involved mature oil charging at about $4 \mathrm{Ma}$, recorded by the second group of oil inclusions containing 15-25 vol.\% gas with blue-white fluorescence. According to quantitative grain fluorescence (QGF) and rock pyrolysis analysis, an ancient oil reservoir existed with an oil-column height of about $350 \mathrm{~m}$, and the paleo oil-water contact was lower than the present gas-water contact. Under intense thrusting from $3 \mathrm{Ma}$, the ancient oil reservoir was destroyed, with oil escaping through the Kashangtuokai thrust fault, which broke the salt layer, as this layer at that time lay in the brittle deformation domain. The inferred destruction of the ancient oil reservoir is supported by the numerous oil and gas shows at the surface and in shallow layers near the Kashangtuokai fault, as well as the anomalous development of authigenic kaolinite in the gas reservoir, which was enhanced by an open or semiopen system caused by the fault breaking through the salt layer. Subsequently, with increasing burial depth to more than $3000 \mathrm{~m}$, the fault that had cut through the salt layer annealed because the salt layer then lay within the ductile deformation domain. The higher overpressure that occurred during the third gas charging at about $2 \mathrm{Ma}$ reflected the annealing of the fault in the salt layer, favoring late gas accumulation and preservation. The evolution of the Kela-2 gas field provides an important case study for understanding the role of the salt layer crossing the brittle-plastic transition and the dynamic evolution of the salt caprock in salt-containing foreland basins.

\section{Introduction}

The Kuqa foreland basin is an important target for natural gas exploration and development in Northwest China and contains hydrocarbons mainly in the Kelasu thrust belt.
Several large gas fields have been discovered in the foreland basin, including Kela-2, Dabei-1, Dabei-3, Keshen-2, Keshen-5, and Keshen-8, with proven reserves of trillions of cubic meters of gas. The Kela-2 gas field is the largest gas field in the Kuqa foreland basin and is characterized by 
large proven gas reserves $\left(2840.29 \times 10^{8} \mathrm{~m}^{3}\right)$, high gas reserve abundance $\left(>53.2 \times 10^{8} \mathrm{~m}^{3} / \mathrm{km}^{2}\right)$, a high degree of gas filling (nearly 100\%), high pressure (pressure coefficient of up to 1.95-2.20), and high gas yield $\left(>20 \times 10^{4} \mathrm{~m}^{3} / \mathrm{d}\right)$. Given the development of a gas field of such large size and favorable characteristics in a complex foreland thrust belt, the Kela-2 gas field discovery has attracted particular attention from petroleum geologists. Since the discovery of the Kela-2 gas field in 1997, numerous studies have been made of its geological characteristics, oil and gas sources and formation conditions, the genesis of the abnormally high pressure, and hydrocarbon accumulation processes and mechanisms [1-15]. These previous studies have established that the main geological conditions favoring the formation of the Kela-2 gas field are an adequate gas supply, excellent sealing barrier, good reservoir quality, complete anticlinal trap, efficient migration pathway, and late gas accumulation. Various lines of evidence, including the occurrence of bitumen and fluid inclusions, show that oil charge once took place in the Kela-2 gas field [13-15], but the scale/size of the ancient oil reservoir remains unclear, as does the process by which the reservoir evolved into the present dry gas field.

This study used fluid inclusion analysis, Raman spectroscopy, quantitative grain fluorescence (QGF) analysis, field emission-scanning electron microscopy (FE-SEM), basin modeling, and hydrocarbon geochemistry to analyze the multiperiod hydrocarbon filling process and accumulation history of the Kela-2 gas field. The microscopic fluid inclusion evidence and the inferred multistage fluid inclusion evolution coincide closely with the geological evidence, as well as with the position and conditions of the brittle-ductile transition in salt rock and the evolution of the effectiveness of the salt caprock seal.

\section{Geological Setting}

The ENE-WSW-trending Kelasu structural belt is located in the north of the Kuqa foreland basin, a part of the Tarim basin, and lies adjacent to the South Tianshan orogenic belt to the north and the Baicheng Sag to the south (Figure 1(a)). Vertical and oblique shear during the South Tianshan orogeny formed a series of strongly deformed thrust structures in the Kuqa foreland basin $[1,2]$. The thrust deformation shows pronounced stratification in the Paleogene salt rock [16-19]: in the upper salt layer, thrust faults and faultrelated folds have formed by slip within the salt rock, whereas in the Mesozoic subsalt layer, some thrust faults have cut through the base of the layer, forming a series of imbricate thrust faults and related folds (Figure 1(b)). The Kelasu structural belt can be divided into the northern and southern Keshen zones, separated by the Kelasu Fault [20]. Structural styles in the Kela zone are characterized by large gentle synclinal structures with shallow depth formed by thrusting on the high-angle Kelasu Fault, whereas structural styles in the Keshen zone are characterized by wedge fault blocks with greater depth and bounded by the Kelasu and north Baicheng Faults (Figure 1(b)). Slip surfaces have enabled the formation of a series of thrust faults with uniform dip, with intervening anticlines, forming arcuate thrust-imbricated structures in the vertical dimension that join at depth (Figure 1(b)). The Kela-2 gas field is located in the Kela zone, and the Dabei, Keshen-1, Keshen-5, and Keshen- 8 gas fields are located in the Keshen zone.

In the Kela-2 gas field, the main gas-bearing layers are the $\mathrm{K}_{1}$ bs sandstone, $\mathrm{E}_{1-2} \mathrm{~km}$ dolomite, and bottom sandstone overlain by the $\mathrm{E}_{1-2} \mathrm{~km}$ gypsum and salt layer (Figure 2). A map of the structure of the $\mathrm{E}_{1-2} \mathrm{~km}$ dolomite (Figure 2(a)) shows that the Kela-2 structure is an anticline with a long axis measuring $18 \mathrm{~km}$ and a short axis measuring $4 \mathrm{~km}$. The long axis trends approximately E-W, although it turns to the NE-SW between wells KL201 and KL2, giving the Kela-2 structure an arc shape bulging toward the south in plan view. In the southern flank of the anticline, a series of small NW- and NE-trending thrust faults are developed. These faults are located within the gas reservoir, making the $\mathrm{E}_{1-2} \mathrm{~km}$ dolomite, basal sandstone, and $\mathrm{K}_{1}$ bs sandstone connect in the vertical dimension and thereby forming a unified hydrocarbon system, with a unified gas-water contact at an elevation of $-2468 \mathrm{~m}$ (depth of $3935 \mathrm{~m}$ ) (Figures 2(a)-2(c)).

The average depth of the Kela- 2 gas reservoir is $3825 \mathrm{~m}$, the average temperature of the strata is $100.6^{\circ} \mathrm{C}$, and the average geothermal gradient is $2.19^{\circ} \mathrm{C} / 100 \mathrm{~m}$. The $\mathrm{E}_{1-2} \mathrm{~km}$ dolomite, basal sandstone, and three lithological members of the $\mathrm{K}_{1}$ bs sandstone belong to the same pressure system, with an average formation pressure of $74.41 \mathrm{MPa}$ and an average pressure coefficient of 1.95-2.20, meaning that Kela-2 is an ultrahigh-pressure gas reservoir [2]. The $\mathrm{CH}_{4}$ content of the gas is $96.9 \%-98.22 \%$, and the $\mathrm{C}_{2} \mathrm{H}_{6}$ content is $0.31 \%-0.53 \%$, with almost no $\mathrm{C}_{2}{ }^{+}$hydrocarbon components, and the dry coefficient of the gas is almost equal to 1.0. The content of nonhydrocarbon gases is very low, with $\mathrm{CO}_{2}$ contents of $0 \%-1.24 \%$ and $\mathrm{N}_{2}$ contents of $0.6 \%-2.84 \%$. The formation water type is $\mathrm{CaCl}_{2}$, with a total salinity of $12-16.5 \times 104$ $\mathrm{mg} / \mathrm{L}$, showing good closed conditions. Pressure-volumetemperature (PVT) analysis indicates that Kela-2 is a dry gas reservoir with ultrahigh pressure, with the critical pressure and temperature points $(\mathrm{Pc}=4.81$ to $4.96 \mathrm{MPa}, \mathrm{Tc}=-80.6$ to $-79.0^{\circ} \mathrm{C}$ ) lying far from the formation pressure and temperature. However, during the development of the Kela-2 gas field, in addition to a gas yield of $1.05 \times 10^{6} \mathrm{~m}^{3} /$ day, it has also produced a small amount of condensate oil ( $3 \sim 5 \times 10^{-3} \mathrm{~m}^{3} /$ day). By the end of 2010 , the cumulative gas and condensate oil yields were $55.2 \times 10^{8} \mathrm{~m}^{3}$ and $29.8 \times$ $10^{3}$ tons, respectively [13].

\section{Samples and Experimental Methods}

During hydrocarbon migration, in the course of precipitation of cement and healing of microfractures, minor amounts of fluid can be captured as inclusions in the reservoir rocks, which can be analyzed to yield the temperature and pressure that applied at the time of capture [21-25], thereby providing clues to the hydrocarbon filling time $[26,27]$ and the evolution of pore fluids $[28,29]$. Here, we used fluid inclusion analysis to obtain the paleo temperature and pressure, fluid composition, and hydrocarbon filling 


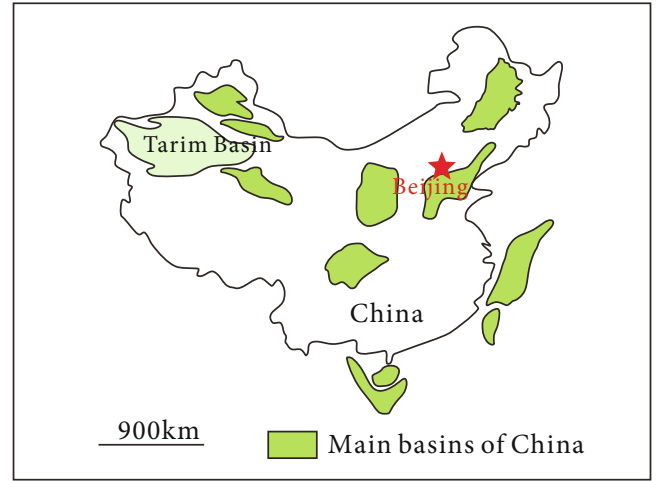

(a)

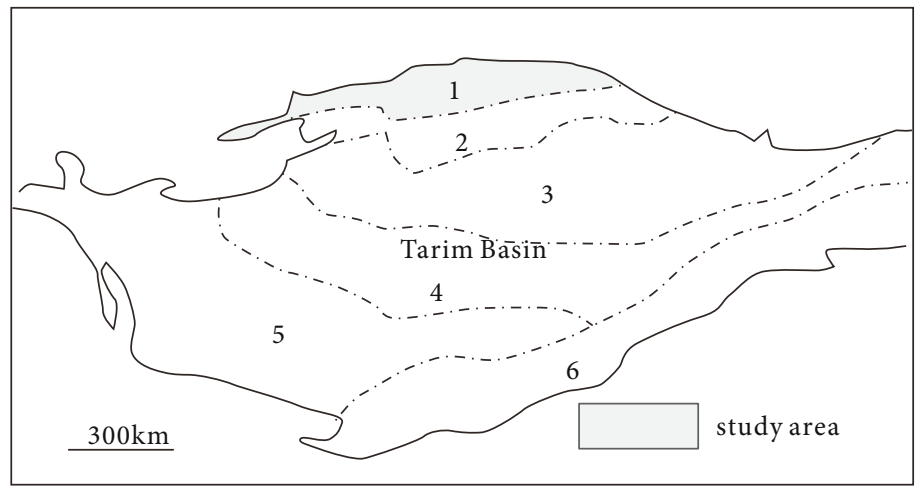

(b)

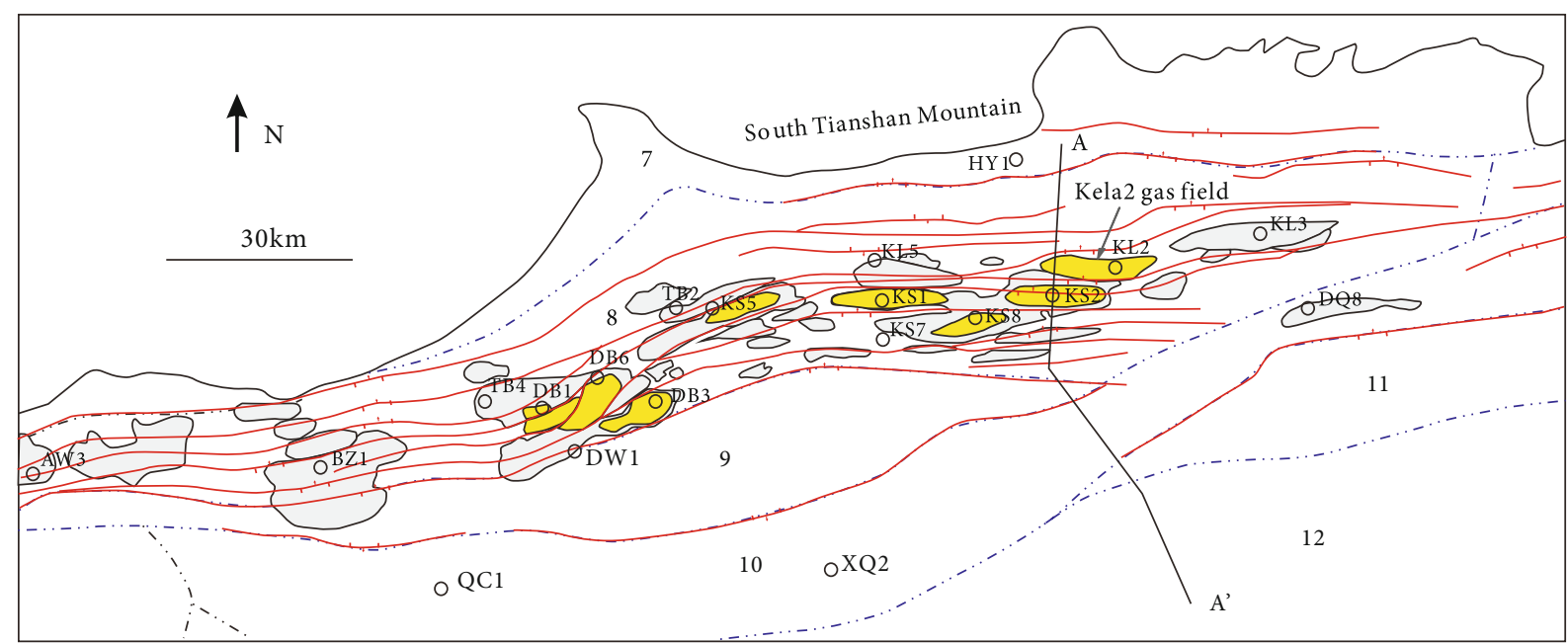

(c)

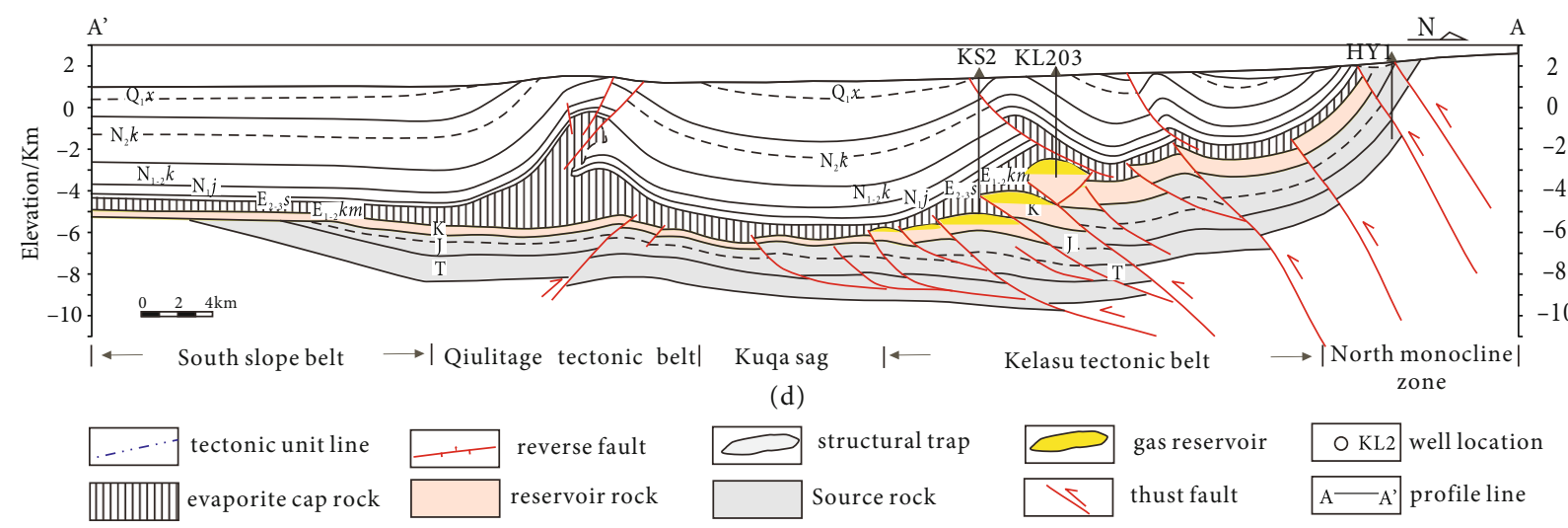

1-Kuqa depression; 2-Tabei uplift; 3- North depression; 4-The central uplift; 5-Southwest depression; 6-South east depression;

7-North monocline zone; 8-Kelasu tectonic belt; 9- Baichengsag; 10-Qiulitagetectonicbelt; 11-Yangxiasag; 12-Southslopebelt

Figure 1: (a) Map of the Kuqa foreland basin, showing the location and geology of the Kela-2 gas field. (b) Geological cross-section A-A' across the Kela-2 gas field.

time, thus enabling a reconstruction of the fluid evolution and the processes of hydrocarbon accumulation.

For this study, 32 core samples of $K_{1}$ bs reservoir were obtained from wells KL2, KL201, and KL205 in the Kela-2 gas field. Thin sections were prepared from the samples to enable systematic microscopic observations and analyses of inclusion microthermometry. Hydrocarbon inclusions and reservoir bitumen were observed using a Zeiss Axio Imager microscope under UV excitation. Temperature measure- ment of inclusions was conducted on a Linkman MDSG600 microscopic heating-freezing stage with an analytical accuracy of $\pm 0.1^{\circ} \mathrm{C}$. In addition, 16 core samples were systematically collected from a depth range of 3600-4030 $\mathrm{m}$ in well KL201, of which 9 samples were from above the gaswater contact and 7 from the water zone. Quantitative grain fluorescence (QGF) analysis was conducted on these 16 samples. QGF analysis can achieve fast and high-precision detection of fluorescence spectra of crude oil, reservoir 

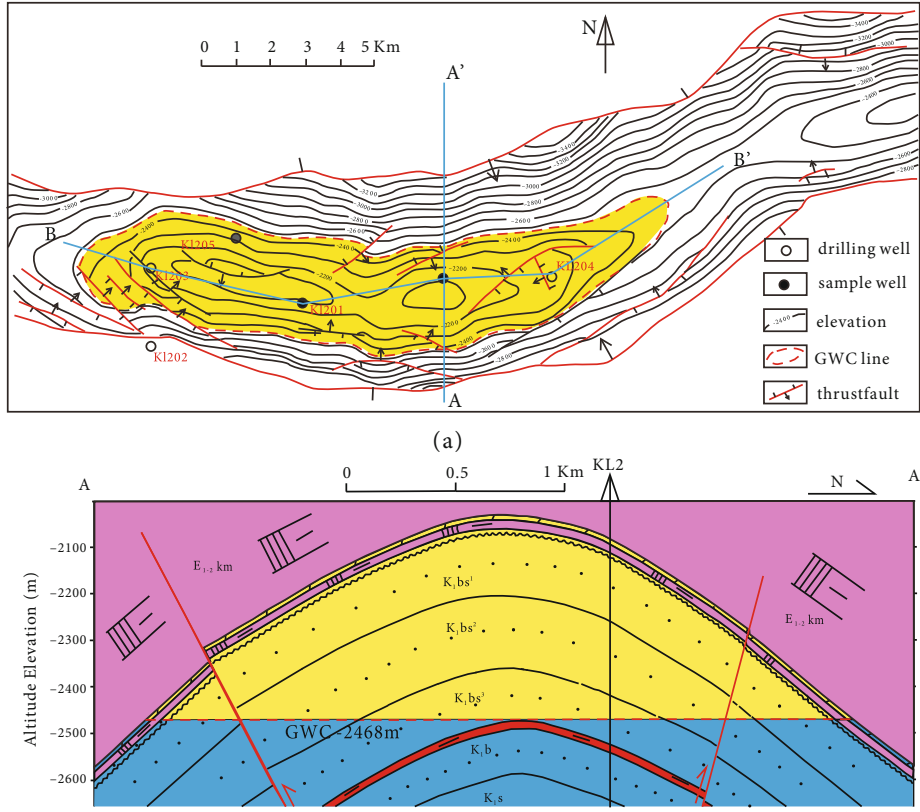

(b)

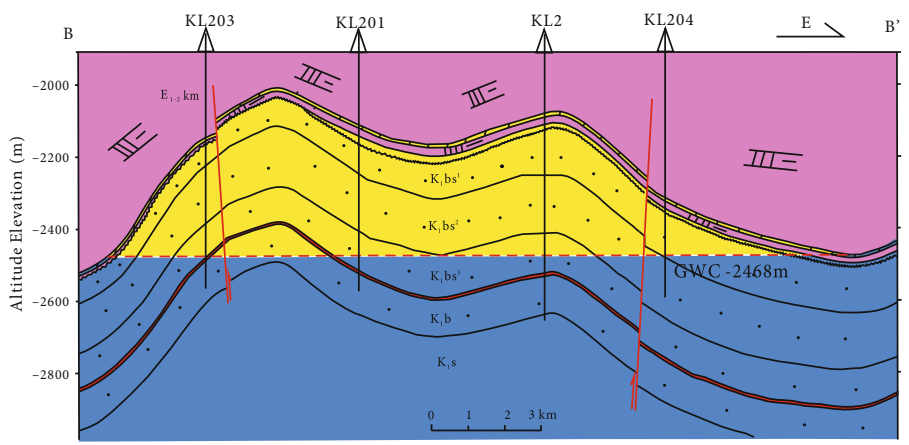

(c)

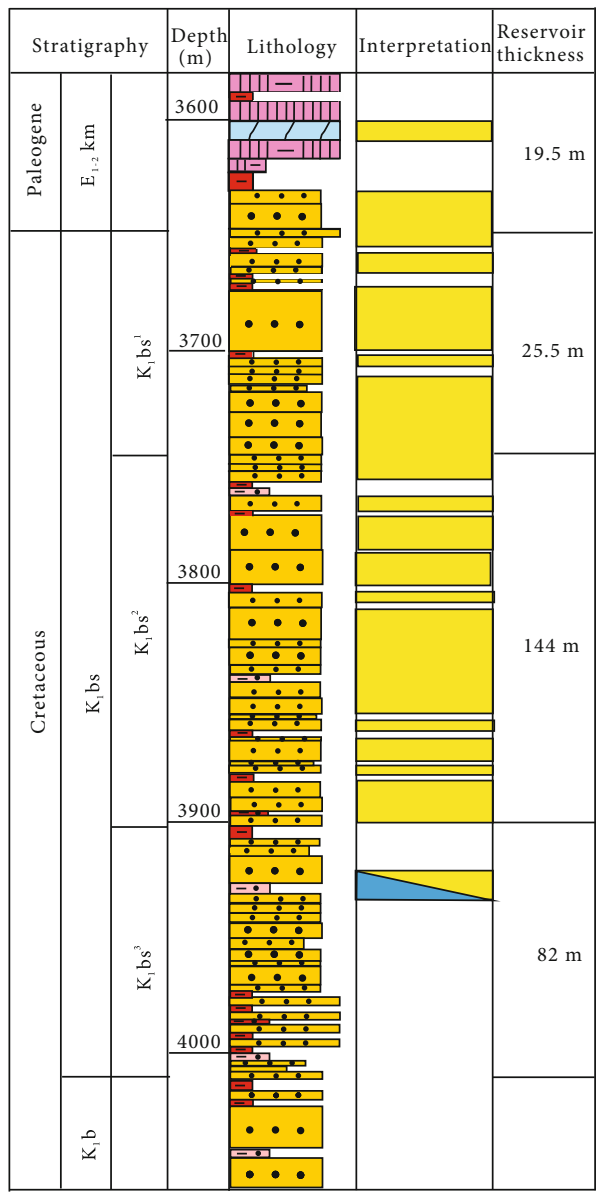

(d)
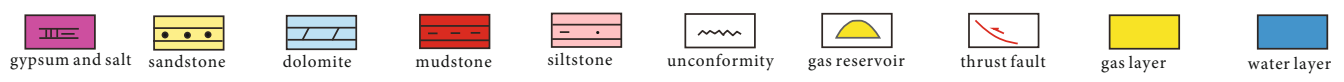

Figure 2: Map and sections showing the structure, reservoir type, and stratigraphy of the Kela-2 gas field. (a) Top surface structural map of the K1bs reservoir of the Kela 2 gas field. (b, c) Geological sections A-A' and B-B' showing gas reservoir type and the unified gas-water contact at an elevation of $-2468 \mathrm{~m}$. (d) Stratigraphy of the Kela-2 gas field.

extracts, and solid grains and can be applied to the identification of the paleo oil-water contact and crude oil components [30-33].

The fluid-trapping temperature and pressure can normally be approximated by using the homogenization temperature and pressure data of aqueous inclusions, provided that the fluid is saturated with $\mathrm{CH}_{4}[29,34]$. The Kuqa foreland basin is a gas-rich basin, so it can be assumed that aqueous inclusions are saturated with methane gas, meaning that the homogenization temperature can be used to represent the trapping temperature. The oil inclusion trapping temperature and pressure were approximated by the Petroleum Inclusion Thermodynamic modeling method [35] combined with the homogenization temperature of aqueous inclusions associated with oil inclusions. The trapping pressure of $\mathrm{CH}_{4}$ containing aqueous inclusions associated with vapor inclusions was determined based on Raman analysis, following the experimental procedures reported by Guo et al. [14].
Triaxial compression tests were conducted on salt samples from unit $\mathrm{E}_{1-2} \mathrm{~km}$ at temperatures of up to $90^{\circ} \mathrm{C}$ and confining pressures of up to $55 \mathrm{MPa}$, using a GCTS RTR1500 triaxial testing system. Salt samples for the triaxial compression tests were taken from the Baicheng salt plant located in the Kuqa basin. The samples were homogeneous with respect to mineralogy, grain size, and chemical content. Irregular salt blocks were carefully cut in the form of intact cylindrical specimens with a height of $50 \mathrm{~mm}$ and a diameter of $25.4 \mathrm{~mm}$.

\section{Results}

4.1. Fluid Inclusion Petrography and Microthermometry. On the basis of petrographic observations and hydrocarbon inclusion characteristics, three different groups of hydrocarbon inclusions are recognized [13, 14]. Group 1 consists of oil inclusions with a low gas/liquid ratio containing 8- 


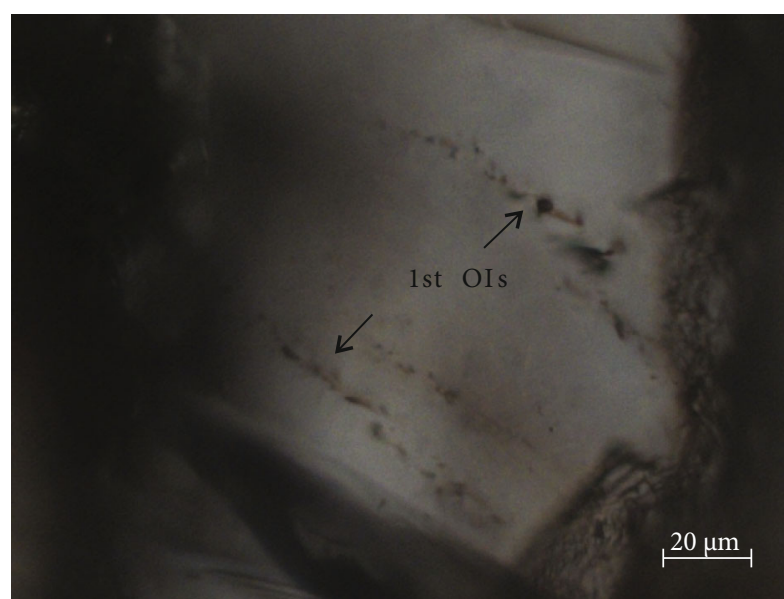

(a)

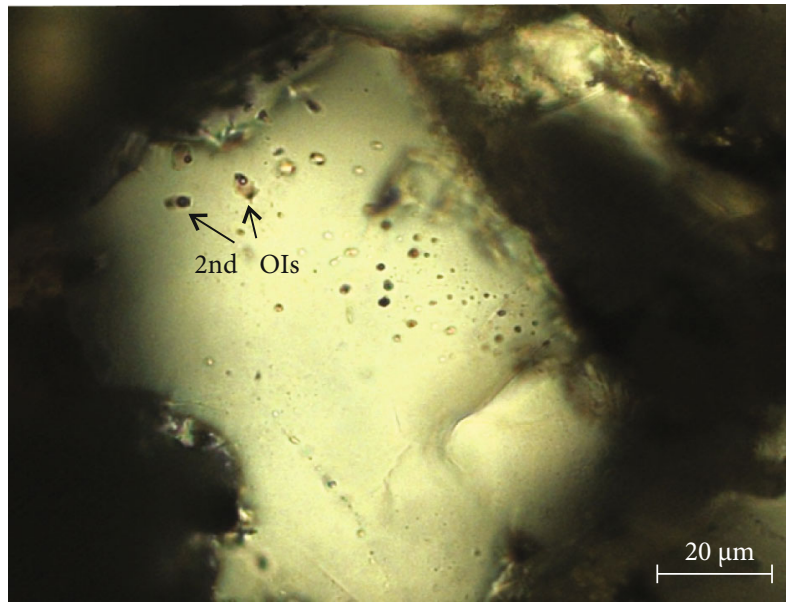

(c)

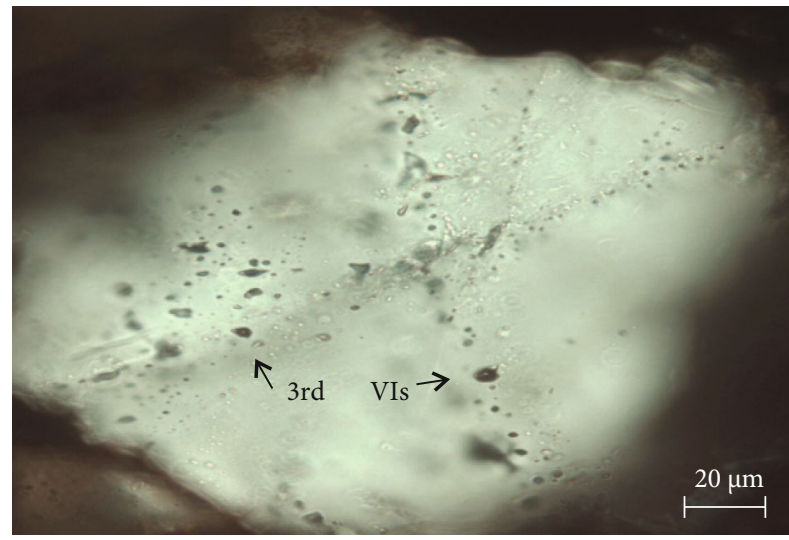

(e)

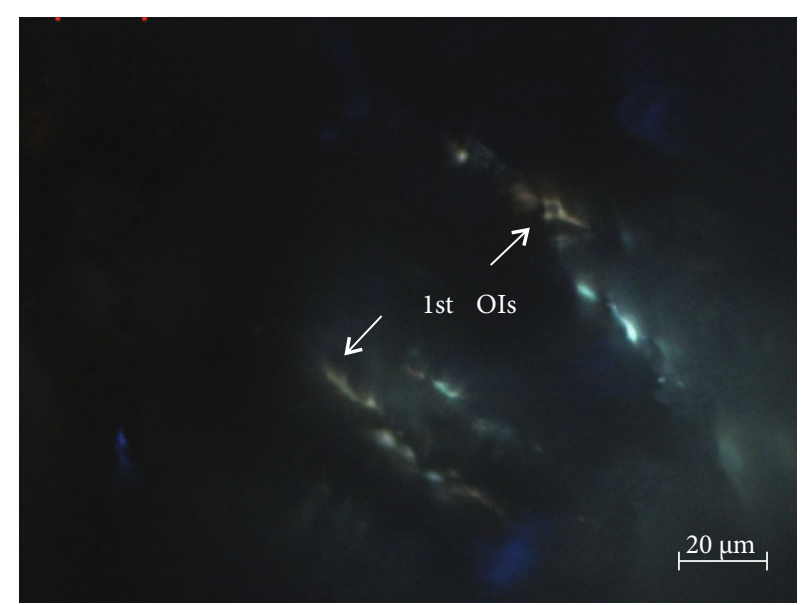

(b)

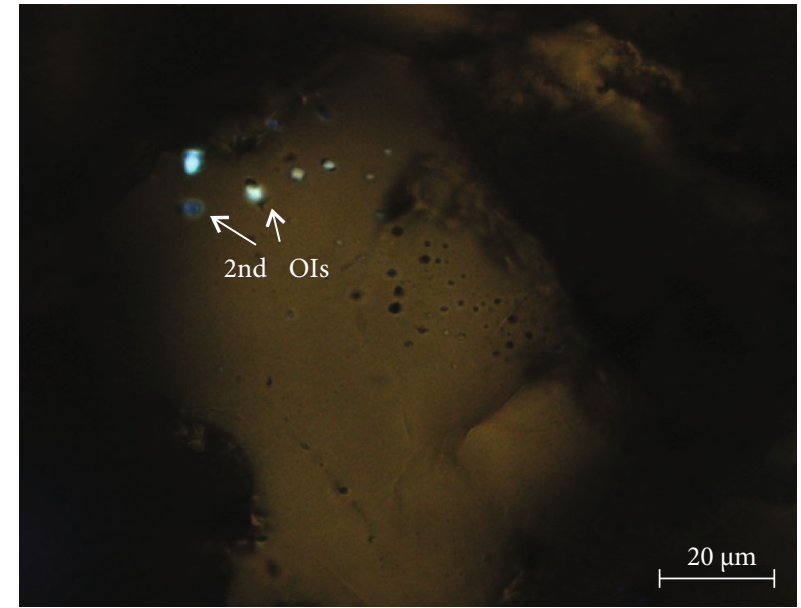

(d)

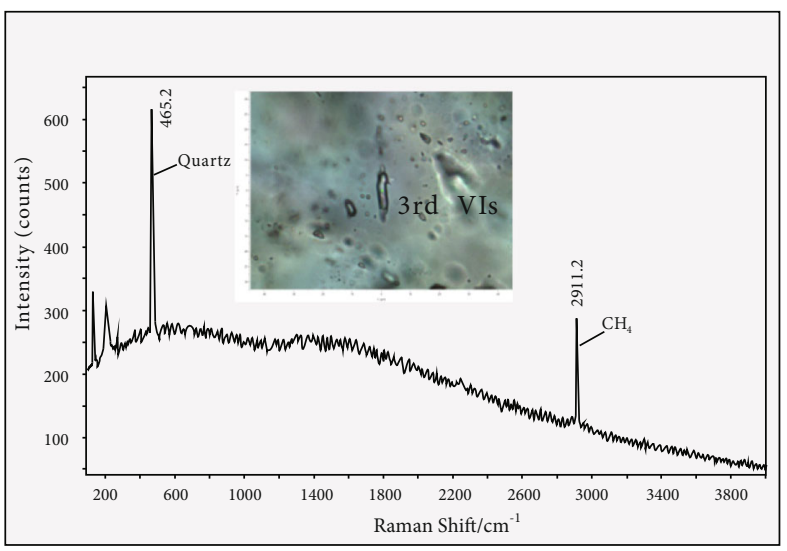

(f)

FIGURE 3: Representative photomicrographs of the three groups (episodes) of petroleum inclusions in the $\mathrm{K}_{1}$ bs reservoir in the Kela-2 gas field. (a) Oil inclusions of group 1 located along annealed microfractures in a quartz grain, plane-polarized light. (b) UV fluorescence photomicrograph of the area shown in (a). (c) Oil inclusions of group 2 located along annealed microfractures in a quartz grain, planepolarized light. (d) UV fluorescence photomicrograph of the area shown in (c), combined with weakly polarized light. (e) Vapor inclusions of group 3 located along annealed microfractures in a quartz grain, plane-polarized light. (f) Raman spectra of the vapor inclusion group in a quartz grain.

25 vol.\% gas. These inclusions are usually near-yellow colored in transmitted light, with yellowish-brown fluorescence and are located in internal cracks in quartz and locally in cal- cite cement (Figures 3(a) and 3(b)). These inclusions represent the early-intermediate oil charge. This group of inclusions is found scattered only in the structurally high 
TABLE 1: Summary of results of fluid inclusion microthermometry.

\begin{tabular}{|c|c|c|c|c|c|c|}
\hline Type & $\begin{array}{l}\text { Mineral } \\
\text { location }\end{array}$ & $\begin{array}{l}\mathrm{G} / \mathrm{V} \\
\text { ratio }\end{array}$ & $T_{h}$ & $T_{m}$ & $\begin{array}{l}\text { Salinity } \\
\text { (wt.\%) }\end{array}$ & Associated petroleum inclusions \\
\hline \multirow{5}{*}{ Aqueous inclusions } & \multirow{5}{*}{ Quartz facture } & $5 \%$ & 95 & -13.5 & 17.34 & \multirow{5}{*}{$\begin{array}{l}\text { Yellowish-brown fluorescent oil } \\
\text { inclusions }\end{array}$} \\
\hline & & $5 \%$ & 96.5 & l & l & \\
\hline & & $5 \%$ & 102.3 & -14.5 & 18.22 & \\
\hline & & $10 \%$ & 108.3 & -14.5 & 18.22 & \\
\hline & & $5 \%$ & 96.7 & -15.2 & 18.8 & \\
\hline \multirow{6}{*}{ Aqueous inclusions } & \multirow{4}{*}{ Ankerite } & $5 \%$ & 122 & -17 & 20.22 & \multirow{6}{*}{$\begin{array}{l}\text { Blue-white fluorescent condensate } \\
\text { inclusions }\end{array}$} \\
\hline & & $5 \%$ & 122 & -17.4 & 20.52 & \\
\hline & & $5 \%$ & 123 & -17 & 20.22 & \\
\hline & & $6 \%$ & 117.4 & -16.8 & 20.27 & \\
\hline & \multirow[t]{2}{*}{ Quartz facture } & $6 \%$ & 120.3 & I & l & \\
\hline & & $8 \%$ & 114.3 & -17.8 & 21.05 & \\
\hline \multirow{6}{*}{ Aqueous inclusions } & \multirow{6}{*}{ Quartz facture } & $5 \%$ & 123 & -12.6 & 16.53 & \multirow{6}{*}{ Methane vapor inclusion } \\
\hline & & $5 \%$ & 140 & -13.3 & 17.17 & \\
\hline & & $10 \%$ & 123.4 & l & l & \\
\hline & & $9 \%$ & 137.6 & -13.1 & 17.09 & \\
\hline & & $8 \%$ & 140.3 & -13.5 & 17.46 & \\
\hline & & $9 \%$ & 141.6 & -12.9 & 16.91 & \\
\hline $\begin{array}{l}\text { Yellowish-brown fluorescent oil } \\
\text { inclusions }\end{array}$ & Calcite & $25 \%$ & 80.0 & l & l & I \\
\hline Blue-white fluorescent oil inclusions & Ankerite & $25 \%$ & 93.7 & l & l & l \\
\hline
\end{tabular}

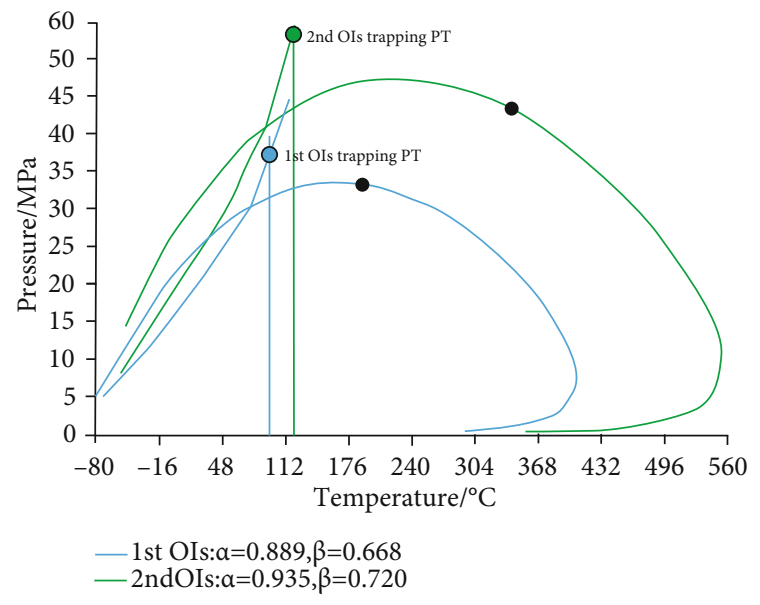

(a)

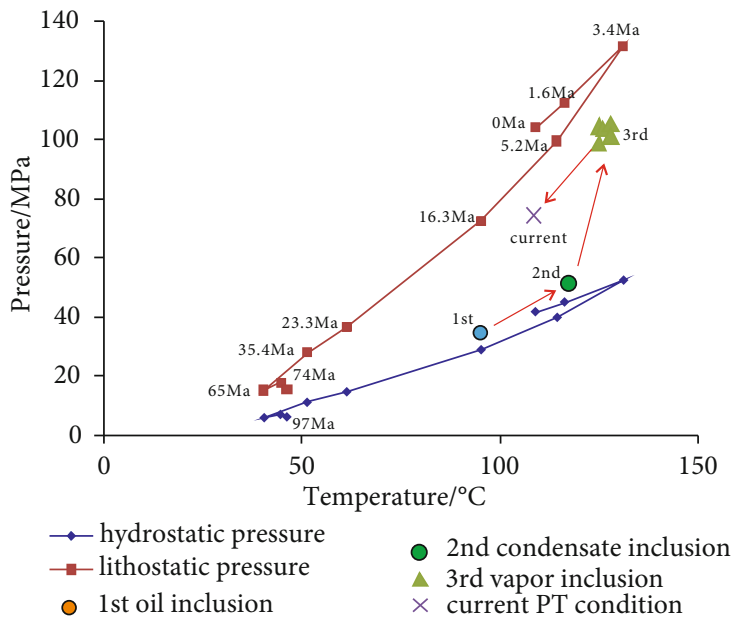

(b)

FIGURE 4: Pressure and temperature evolution of the K1bs sandstone in well KL201, according to fluid inclusion PVT simulation. (a) Results of PVT simulation for determining the trapping pressure and temperature conditions of the oil inclusions (OIs) of groups 1 and 2. (b) Pressure and temperature evolution of the K1bs sandstone in well KL201, showing the evolution from OIs of group 1, to condensate inclusions of group 2, to vapor inclusions of group 3, and the current pressure and temperature conditions.

part of the reservoir, which reflects limited early oil charging. Group 2 consists of oil inclusions with a high gas/liquid ratio containing 15-25 vol.\% gas that occur mainly in the internal cracks of quartz grains and locally in calcite veins and ankerite cement. These inclusions are colorless in transmitted light and are characterized by blue-white fluorescence (Figures 3(c) and 3(d)), representing mature oil charging. This group of oil inclusions is well developed and reflects intensive oil charging. Some bitumen occurs locally at the boundaries of these group 2 oil inclusions. Group 3 gas inclusions are found mainly in transgranular fractures in quartz grains and late calcite veins. They are usually blackbrown colored in transmitted light and are nonfluorescent (Figure 3(e)). The gas composition of these inclusions is mainly $\mathrm{CH}_{4}$, as measured by laser Raman spectroscopy (Figure 3(f)), with $\mathrm{CH}_{4}$ Raman peaks mainly at 2910- 


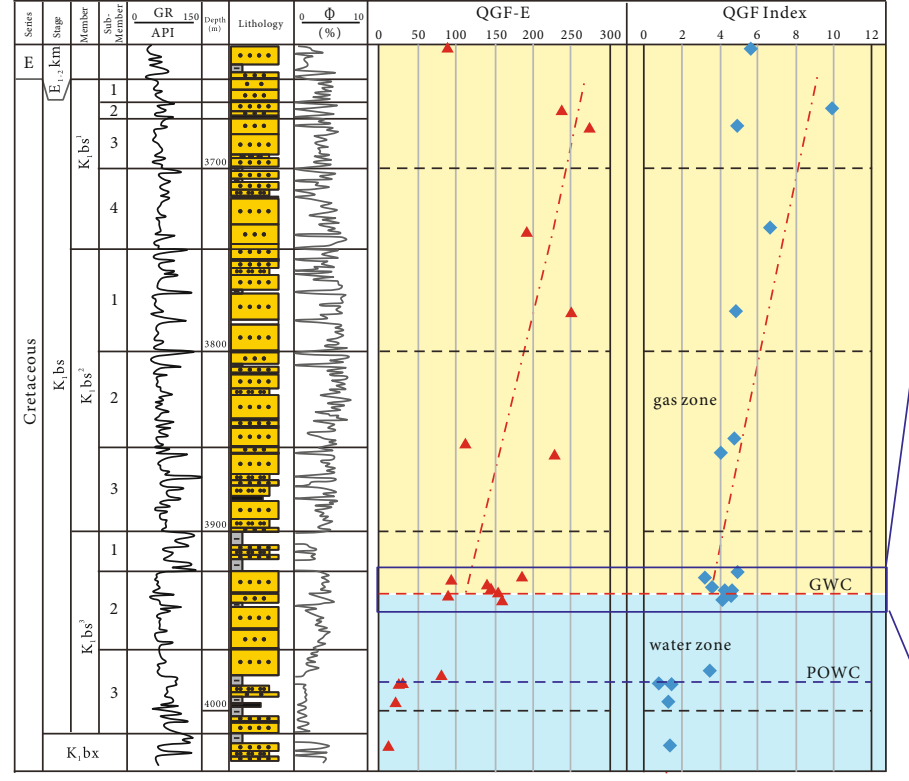

(a)

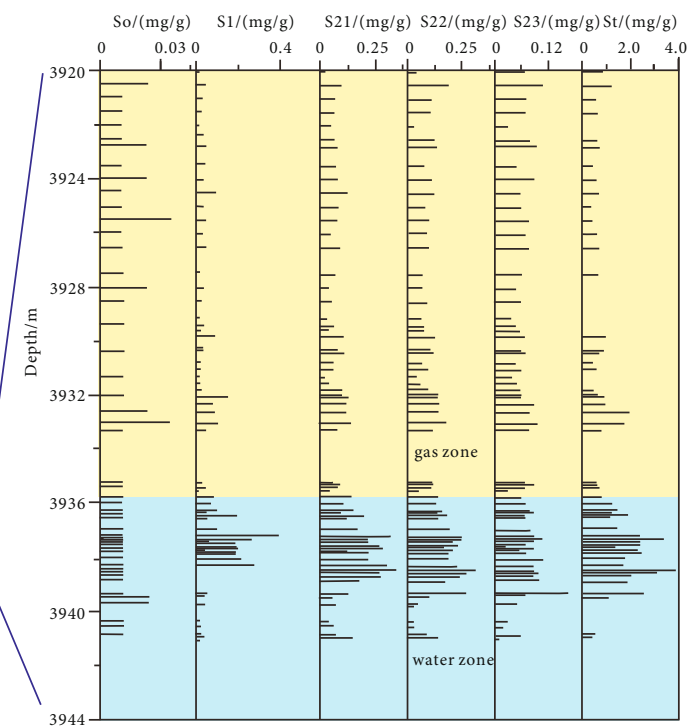

(b)

FIGURE 5: QGF and reservoir pyrolysis profiles for the K1bs reservoir in KL201 well, indicating the existence of an ancient oil reservoir. (a) QGF and QGF-E profiles for well KL201, showing the POWC below the GWC. (b) Reservoir pyrolysis profile showing the characteristics of oil layers in both the gas and water zones. $S_{0}, S_{1}, S_{21}, S_{22}$, and $S_{23}$ represent hydrocarbons detected in unit mass reservoir rocks at $<90^{\circ} \mathrm{C}, 90-$ $200^{\circ} \mathrm{C}, 200-350^{\circ} \mathrm{C}, 350-4500^{\circ} \mathrm{C}$, and $450-6000^{\circ} \mathrm{C}$, respectively, and $S_{t}$ represents the total hydrocarbons in a unit mass of rock (the sum of $S_{0}$ , $S_{1}, S_{21}, S_{22}$, and $S_{23}$ ).

$2912 \mathrm{~cm}^{-1}$, representing late overmature and overpressurized dry gas charging.

Homogenization temperatures $\left(T_{h}\right)$ were measured on oil inclusions and associated aqueous inclusions in quartz microfractures and calcite and ankerite cements. Most of the fluid inclusions are located along healed microfractures in quartz. The measured data for $T_{h}$, final ice melting temperatures $\left(T_{m}\right)$, and salinity data are presented in Table 1. Based on a comparison with the measured $T_{h}$ data of $\mathrm{Yu}$ et al. [15], we excluded some clearly higher $T_{h}$ values measured during the present study, which were assumed to be caused by fluid inclusion reequilibration. According to fluid inclusion microthermometry, group 1 oil inclusions with yellowish-brown fluorescence hosted in early calcite cement homogenized at around $80^{\circ} \mathrm{C}$, and the coeval aqueous inclusions homogenized between 95 and $108^{\circ} \mathrm{C}$. Group 2 oil inclusions with blue-white fluorescence homogenized at around $93^{\circ} \mathrm{C}$, and the coeval aqueous inclusions homogenized between 114 and $123^{\circ} \mathrm{C}$. The aqueous inclusions associated with group 3 gas inclusions yielded higher $T_{h}$ values of $123-142^{\circ} \mathrm{C}$. For fluid inclusions in carbonate minerals, which readily undergo reequilibration and stretching, the measured $T_{h}$ data are commonly higher than the actual $T_{h}$ temperature $[23,36]$. Therefore, the minimum $T_{h}$ temperatures of aqueous inclusions coeval with petroleum inclusions represent the trapping temperature of petroleum. It is thus proposed that the $T_{h}$ of group 1 oil inclusions is $95^{\circ} \mathrm{C}$, of group 2 oil inclusions is $114^{\circ} \mathrm{C}$, and of group 3 gas inclusions is $123^{\circ} \mathrm{C}$.

The salinities of aqueous inclusions associated with petroleum inclusions were calculated from the values of
$T_{m}$. Because the majority of aqueous inclusions are very small, few inclusions were able to be measured for $T_{m}$. The salinity values are related to $T_{h}$ as follows. Group 1 fluid inclusions with a minimum $T_{h}$ of $95^{\circ} \mathrm{C}$ have relatively low salinity (17.3-18.8wt.\% $\mathrm{NaCl}$ equivalent), group 2 fluid inclusions with a minimum $\mathrm{Th}$ of $114^{\circ} \mathrm{C}$ have relatively high salinity (20.2-21.1 wt.\% $\mathrm{NaCl}$ equivalent), and group 3 fluid inclusions with a minimum $\mathrm{Th}$ of $123^{\circ} \mathrm{C}$ have relatively low salinity (16.5-17.5 wt.\% $\mathrm{NaCl}$ equivalent). The salinity of the current reservoir formation water is $12.0-16.5 \times 104 \mathrm{mg} / \mathrm{L}$, corresponding to $10.7-14.2$ wt.\% $\mathrm{NaCl}$ equivalent, which is lower than the salinities of any of the groups of inclusions.

4.2. Fluid Inclusion Pressure. The oil inclusion trapping temperature and pressure for group 1 and group 2 inclusions were approximated using the PIT modeling method proposed by Thiery et al. [35], which considers the $T_{h}$ and gas/volume ratio of oil inclusions, as well as the $T_{h}$ of aqueous inclusions associated with oil inclusions (Figure 4(a)). The trapping pressures of $\mathrm{CH}_{4}$-containing aqueous inclusions associated with gas inclusions were determined based on the vapor bubble pressure at room temperature using laser Raman spectroscopy, $T_{h}$, and the salinity of aqueous fluids [37]. Combining fluid inclusion $T_{h}$ values with the burial and thermal history, the evolution of fluid pressure and salinity over geological time can be reconstructed. The results are shown in Figure 4(b). During the first oil charging at about $12 \mathrm{Ma}$, the pressure was just above the hydrostatic pressure, and the water salinity was about $17.3-18.8 \mathrm{wt} . \%$ $\mathrm{NaCl}$ equivalent. During the second oil charging at about $4 \mathrm{Ma}$, the pressure coefficient increased slightly up to 1.3 , 


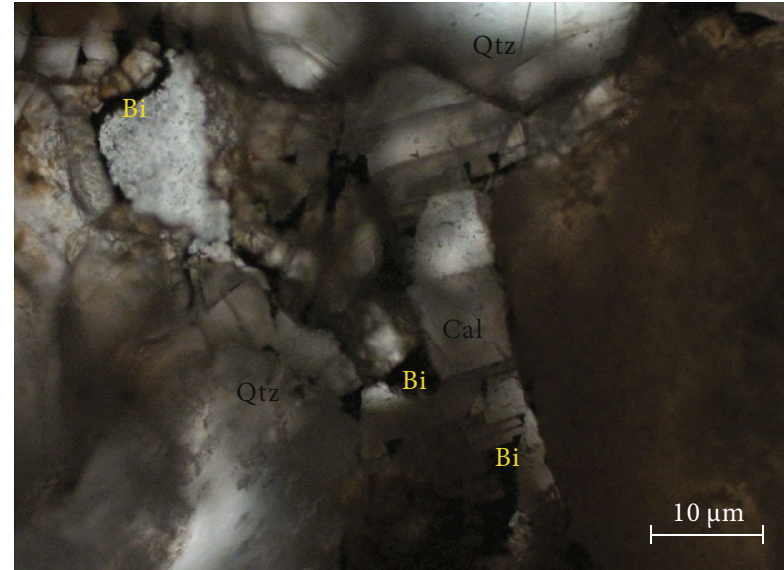

(a)

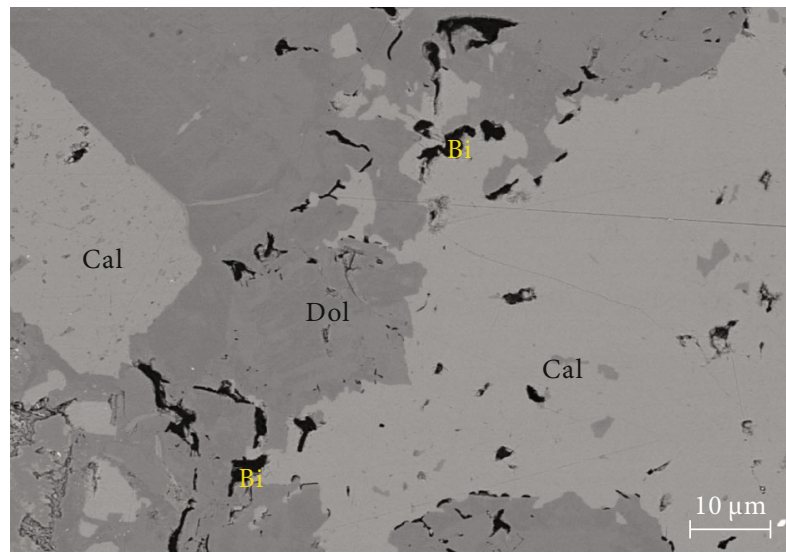

(c)

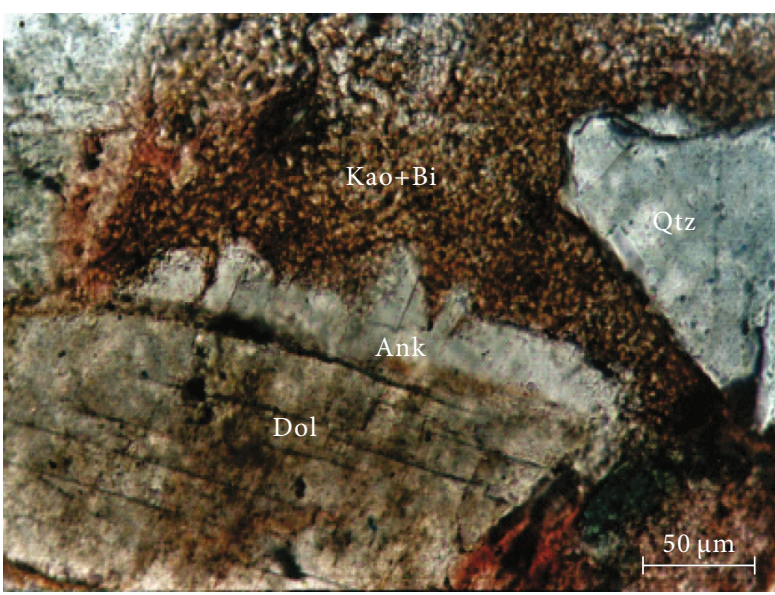

(e)

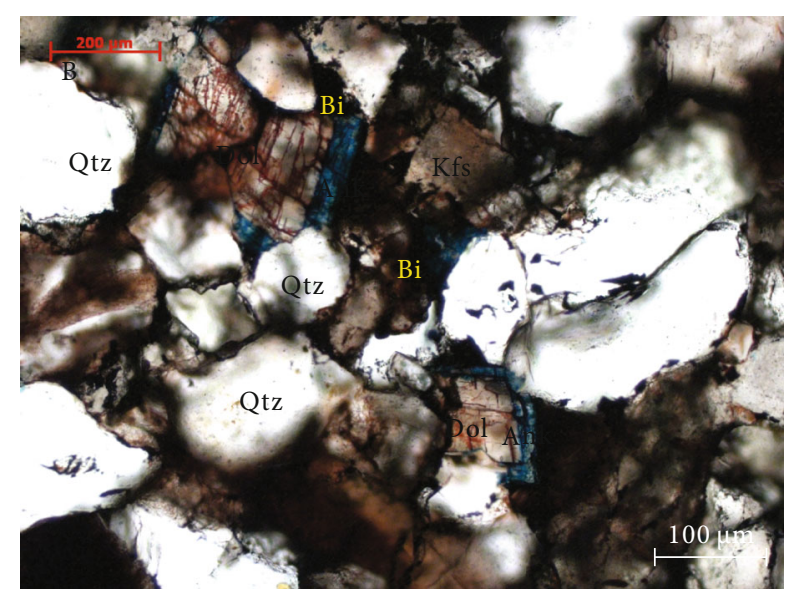

(b)

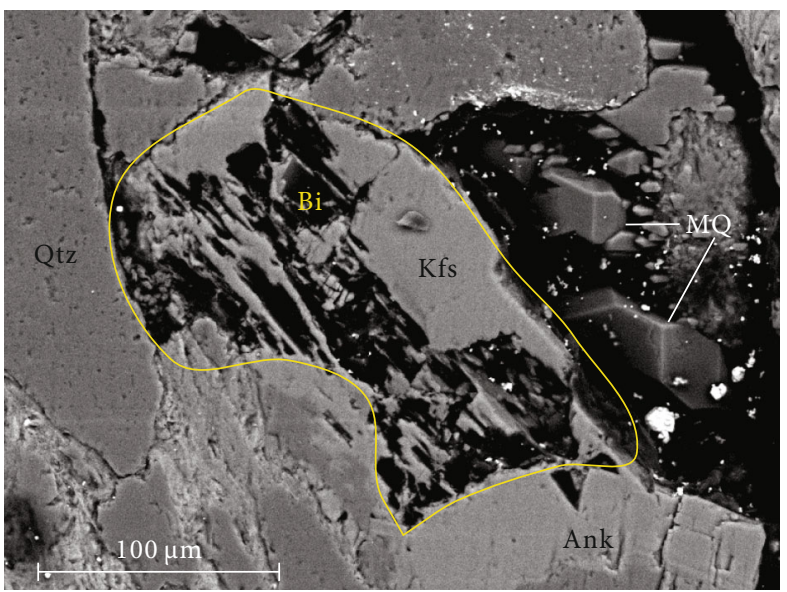

(d)

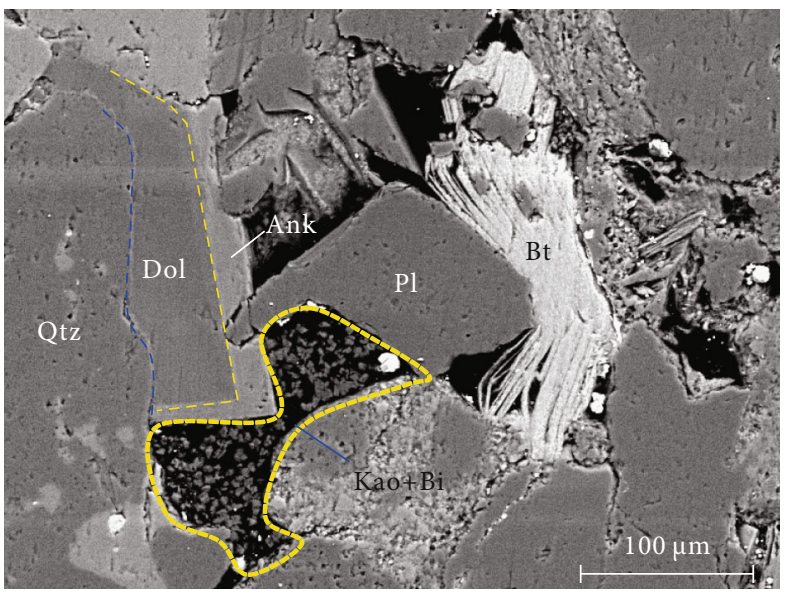

(f)

FIGURE 6: Representative photomicrographs of bitumen and residual oil occurrence in the reservoir of the Kela 2 gas field. (a) Residual pores and intergranular calcite cement and residual bitumen, plane-polarized light. (b) Intergranular dolomite and ankerite cement and residual bitumen, plane-polarized light. (c) Bitumen in internal pores within calcite and dolomite, FE-SEM image. (d) Bitumen in K-feldspar dissolution pores, BSE image. (e) Pore-filling kaolinite and bitumen in residual pores after dolomite and ankerite formation, planepolarized light. (f) Pore-filling kaolinite and bitumen, coeval with microquartz grains, BSE image. Qtz: quartz; Kfs: K-feldspar; Dol: dolomite; Cal: calcite; Bi: bitumen; Ank: ankerite; Kao: kaolinite.

and water salinity increased to $20.2-21.1$ wt.\% $\mathrm{NaCl}$ equivalent. During gas charging at about $2 \mathrm{Ma}$, the pressure coefficient increased substantially to $2.0-2.1$, and water salinity decreased to $16.5-17.5$ wt.\% $\mathrm{NaCl}$ equivalent. During uplift and erosion from 1.6 Ma, the pressure coefficient decreased slightly to 1.95 because of the marked reduction in 


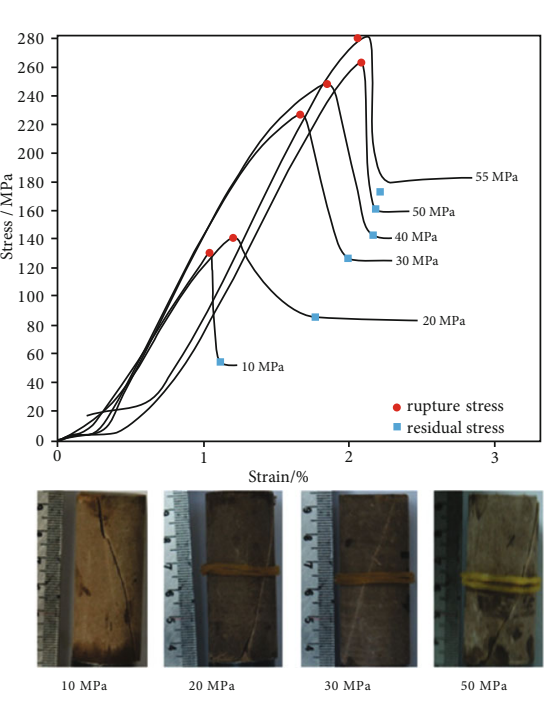

(a)

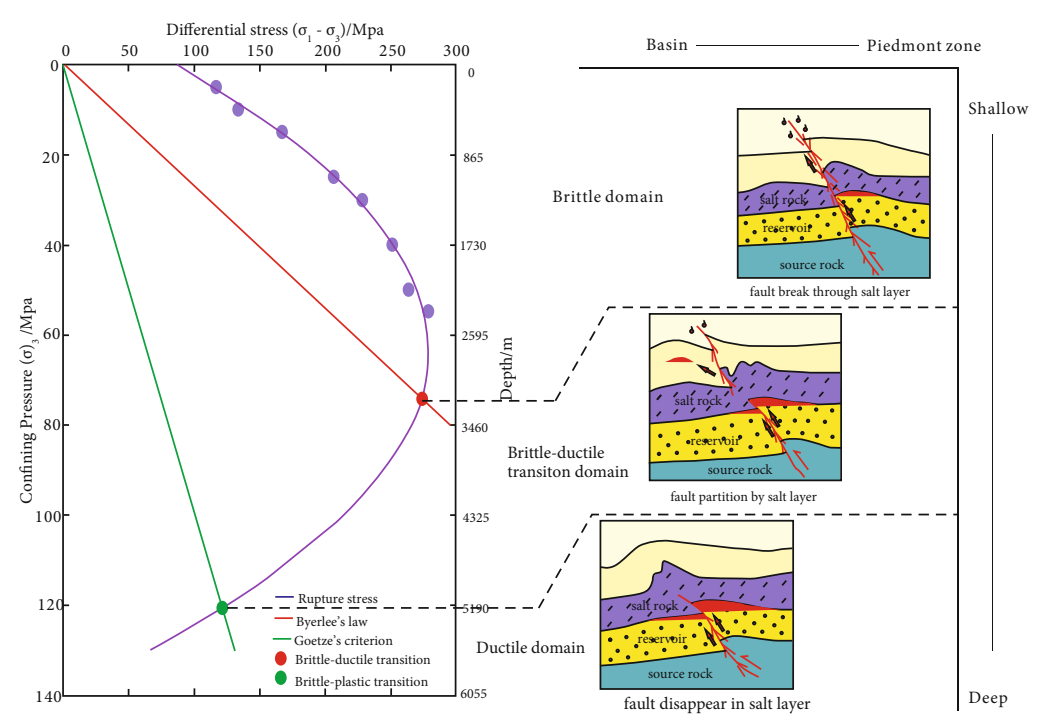

(b)

(c)

FIGURE 7: Results of triaxial compression tests on $\mathrm{E}_{1-2} \mathrm{~km}$ salt rock, showing the conditions of the brittle-ductile transition and different fault-salt combinations in various deformation domains. (a) Triaxial compression test results for $\mathrm{E}_{1-2} \mathrm{~km}$ salt rock samples at different confining pressures. (b) Brittle-ductile transition conditions of Kuqa $\mathrm{E}_{1-2} \mathrm{~km}$ salt rock samples determined by triaxial compression test results and according to Byerlee's law and Goetze's criterion. (c) Sketch map showing the different fault-salt combinations occurring in various deformation domains for salt rock.

temperature, and water salinity decreased to the current 10.7-14.2 wt.\% $\mathrm{NaCl}$ equivalent because of $\mathrm{NaCl}$ precipitation caused by temperature decrease.

4.3. Quantitative Fluorescence. According to quantitative fluorescence analysis of 16 core samples, both the QGF index and QGF-E intensity profiles delineate a residual/ paleo oil-water contact (POWC) at a depth of $3994.5 \mathrm{~m}$ (Figure 5(a)), deeper than the current gas-water contact (GWC) at $3935 \mathrm{~m}$. Above the inferred POWC, the QGF-E intensities are greater than 50 and QGF index values are greater than 4, and both the QGF index and QGF-E intensity profiles display an increasing trend upwards, which corresponds to the typical characteristics of the fluorescence profile of paleo oil reservoirs [33]. The QGF-E spectral signature is typical of that obtained from known residual oil enriched with polar and asphaltene fractions [13].

4.4. Bitumen Occurrence. Abundant black dry bitumen was identified in the samples by microscopic observations. The bitumen is distributed mainly in residual intergranular pores and formed later than quartz overgrowths and carbonate cement (Figures 6(a) and 6(b)). FE-SEM observations have identified well-developed liquid oil in nanopores of the $\mathrm{E}_{1-}$ ${ }_{2} \mathrm{~km}$ dolomite reservoir in well KL201 [13]. The crude oil in the nanopores is isolated from the outside and is well preserved without the influence of gas washing during the late stage of Himalayan movement. This shows the existence of early oil charging in the Kela-2 gas reservoir. Scanning electron microscope (SEM) analysis reveals bitumen in the pores and holes where calcite is replaced by dolomite in the $\mathrm{E}_{1-}$ ${ }_{2} \mathrm{~km}$ dolomite reservoir of well KL201 (Figure 6(c)). In addition, typical three-phase hydrocarbon inclusions containing gas, oil, and solid bitumen formed initially in the reservoir, and the shapes of these inclusions are well preserved, indicating that no leakage occurred (Figures 3(c) and 3(d)). By implication, the solid bitumen phase was trapped during the oil deasphalting process caused by gas washing of the crude oil, and the observed presence of bitumen supports the inferred occurrence of gas washing.

4.5. Triaxial Compression Tests of Salt Rock. Results of triaxial compression testing of salt rock with confining pressure and temperature show that the $\mathrm{E}_{1-2} \mathrm{~km}$ salt rock underwent brittle deformation at low confining pressure and temperature, and plastic deformation at high confining pressure and temperature (Figure $7(\mathrm{a})$ ). With increasing depth of burial, the mechanical properties of salt rock are known to change from brittle to brittle-ductile and finally ductile $[38,39]$. According to the experimental results of this study, the brittle-ductile transition and brittle-plastic transition depths of salt rock in the Kuqa basin are $3000 \mathrm{~m}$ and $5000 \mathrm{~m}$, respectively (Figure 7(b)). Deformation of the Paleogene salt-dominated evaporate deposits in the Kuqa basin is thus controlled mainly by the relatively ductile salt rocks. In other words, above a depth of $3000 \mathrm{~m}$, salt rock behaves as a brittle material under the strong extrusive stress of the foreland thrust belt, with faults forming and cutting through salt layers under this stress, resulting in loss of oil and gas (Figure $7(\mathrm{c})$ ). In contrast, below a depth of $3000 \mathrm{~m}$, salt rock is dominated by ductile deformation. During the process of extrusion and deformation, ductile salt layers accommodate tectonic stress by plastic flow, and the salt cap rock is not easily broken (Figure $7(\mathrm{c})$ ). Even preexisting faults can disappear/anneal in the salt layers owing to salt plastic-flow deformation, which favors subsalt oil and gas preservation. 


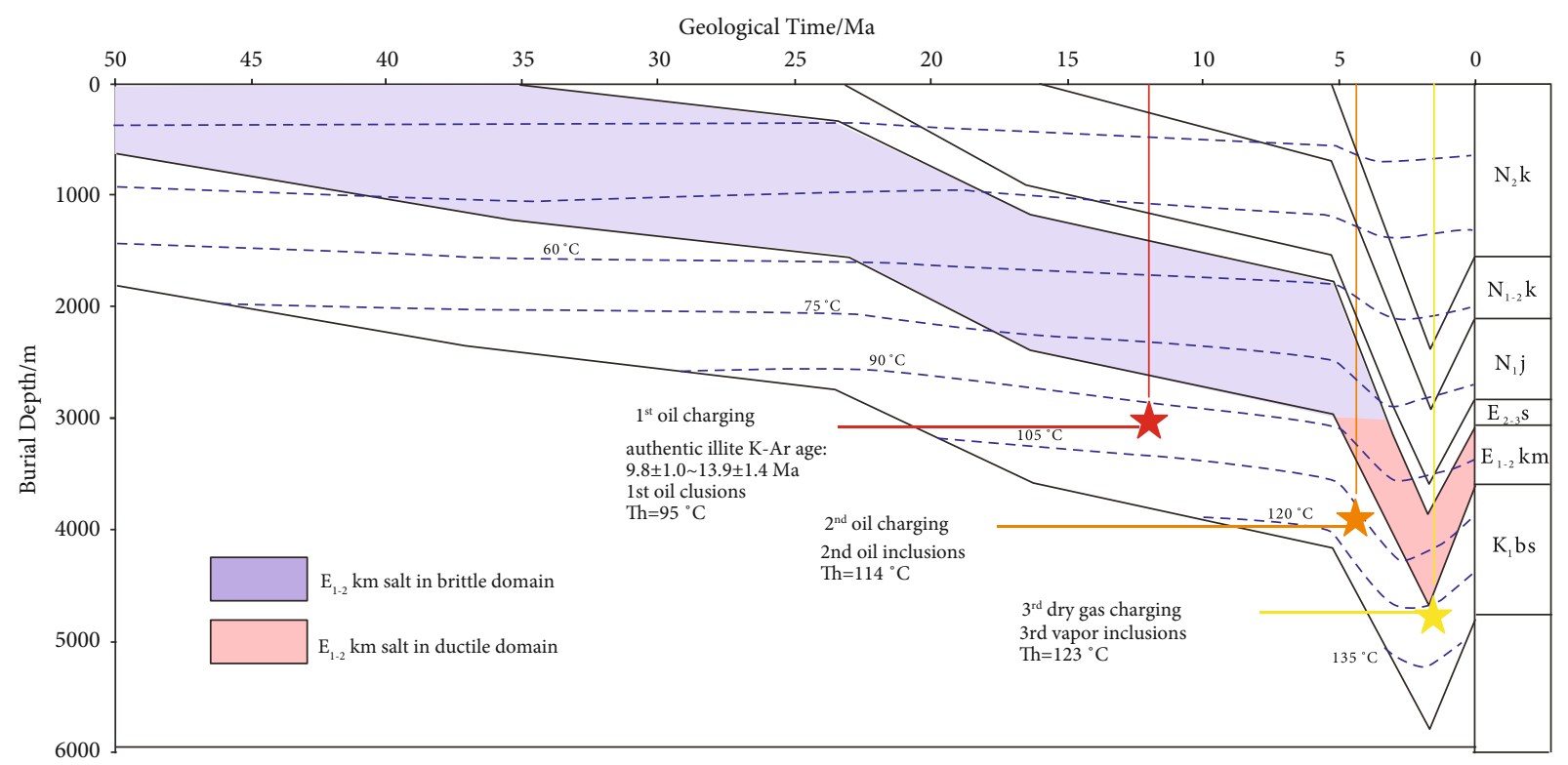

(a)

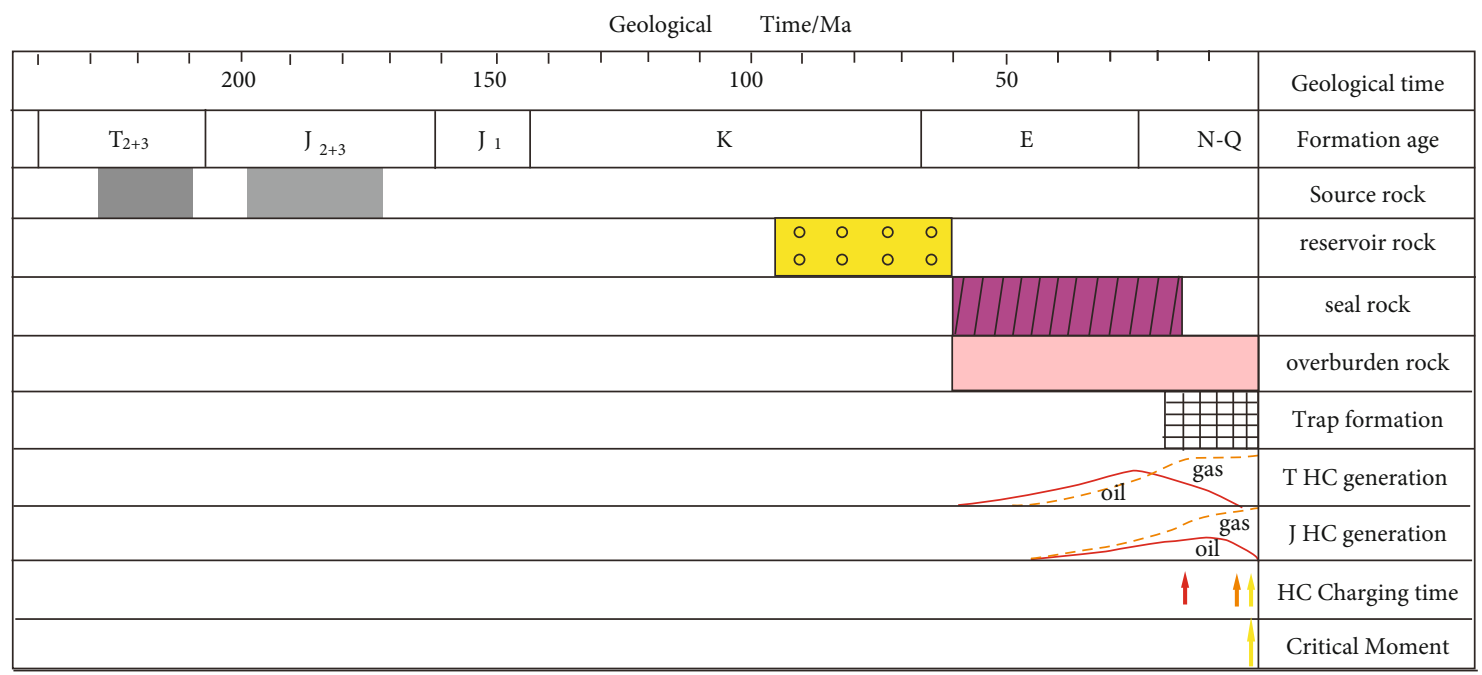

(b)

Figure 8: Burial and geological history for the Kela 2 gas field, showing hydrocarbon charging periods. (a) Burial and thermal history diagram for well KL2, showing the three periods of oil and gas charging according to fluid inclusion analysis. (b) Petroleum system history for the Kela-2 gas field.

\section{Discussion}

5.1. Timing and Duration of Hydrocarbon Charging. The results of this study, combined with the burial and thermal history of well KL2, indicate the first oil charging occurred at around $12 \mathrm{Ma}$ (Figure 8(a)). K-Ar dating of authigenic illite generally represents the earliest time of oil and gas accumulation [40]. K-Ar dating of authigenic illite of the Kela-2 gas field has yielded an age range of $13.9 \pm 1.4$ to $9.8 \pm 1.0$, which indicates that the charging time of the early oil was during the period of deposition of units $\mathrm{N}_{1} \mathrm{j}-\mathrm{N}_{1-2} \mathrm{k}$ (Figure 8(a)). The ages of authigenic illite of the $\mathrm{K}_{1}$ bs reservoir in well DN-2, also within the Kuqa thrust belt, range from 25.5 to $15.5 \mathrm{Ma}$ [41], consistent with the age range of the Kela-2 gas field. All of these results indicate that the early oil accumulation in the Miocene was a regional event, as during this time the Triassic source rock entered the peak hydrocarbon generation stage (Figure $8(\mathrm{~b})$ ). The second oil charging period was at around $4 \mathrm{Ma}$, belonging to the early-middle part of the deposition of $\mathrm{N}_{2} \mathrm{k}$ (Figure $8(\mathrm{a})$ ). At this stage, the Jurassic source rock was already in the peak hydrocarbon generation stage (Figure 8(b)). The gas charging stage occurred at either 3-2 Ma (before erosion) or 2$1 \mathrm{Ma}$ (after erosion). Given that uplift and erosion generally favor oil and gas accumulation, it is inferred that the timing of gas charging was about $2 \mathrm{Ma}$ (Figure $8(\mathrm{a})$ ), when the Triassic and Jurassic source rocks were in the overmature gas generation stage (Figure 8(b)).

The Himalayan orogeny was the period when structures and traps in the Kuqa foreland basin were formed and thus 
played an important role in the accumulation and distribution of oil-gas $[42,43]$. The late Himalayan was the main period of structural deformation and oil-gas accumulation $[42,44]$. The three periods of hydrocarbon charging, as determined by fluid inclusion analysis (Figure 8(a)), correspond with the history of tectonic activity and the stages of hydrocarbon generation and expulsion (Figure $8(\mathrm{~b})$ ).

5.2. Scale of the Ancient Oil Reservoir. According to QGF analysis, combined with hydrocarbon fluid inclusion analysis, an ancient oil reservoir of about $350 \mathrm{~m}$ oil-column height once existed in the current gas and water zones (Figure 5(a)). The residual bitumen and fluorescence in pores and cracks further indicate the existence of the ancient oil reservoir. Results of rock pyrolysis of reservoir samples between depths of 3920 and $3944 \mathrm{~m}$ near the GWC show that samples in the current gas layer above $3935 \mathrm{~m}$ all have high values of $S_{0}, S_{1}, S_{21}, S_{22}$, and $S_{23}$, with a maximum $S_{t}$ (the sum of $S_{0}, S_{1}, S_{21}, S_{22}$, and $S_{23}$ ) value of $0.2 \mathrm{mg} / \mathrm{g}$, consistent with an oil layer (Figure 5(b)). In comparison, samples in the current water layer below $3935 \mathrm{~m}$ have higher pyrolysis values, with a maximum $S_{t}$ value of $0.4 \mathrm{mg} / \mathrm{g}$, signifying more oil. The reservoir rock pyrolysis values in both the gas and water layers are consistent with the characteristics of an oil layer, further supporting the proposition that the Kela-2 gas field was once an ancient oil reservoir and that the ancient oil column was greater than the current gas column.

The measured reflectance of bitumen is quite low, with two groups of values centered around $1.07 \%$ and $0.47 \%$, meaning that this is not oil-cracking bitumen [45]. According to the burial history of well KL201, the maximum temperature experienced by the $\mathrm{K}_{1}$ bs reservoir was only $135^{\circ} \mathrm{C}$, below the temperature that would allow oil cracking into gas [46]. In addition, there is no obvious biodegradation of the bitumen extract in a GC-MS diagram, indicating that the observed bitumen is not of biodegradation origin. Rather, it is concluded that the bitumen is the result of washing of early crude oil by natural gas $[13,45,47]$.

5.3. Mode of Destruction of Ancient Oil Reservoir. In the absence of any damage or leakage to the Kela-2 ancient oil reservoir, late dry gas charging would have been unable to completely transform an ancient oil reservoir with an oilcolumn height of $350 \mathrm{~m}$ into the present dry gas reservoir. The most likely explanation is that the Kela-2 ancient oil reservoir was damaged before the late dry gas was charged. In such a process, a large volume of crude oil would have been lost, leaving only a small amount in the pores of the reservoir, as recorded by the filling of crude oil and the process of gas washing. The geological evidence for the destruction of the Kela-2 ancient oil reservoir is as follows. (1) the Kela-2 structure is located in the region of most intense fault movement and tectonic deformation in the Kelasu structural belt (Figure 1). Also, the $\mathrm{E}_{1-2} \mathrm{~km}$ unit overlying the regional cap rock in the Kela-2 structure is thinner than the adjacent Kela- 3 and Kela- 1 structures. In terms of the ease with which fluid in the abnormally high-pressure system of subsalt K-E could break through the overlying cap rock, the Kela-2 structure would have been a location of fluid leak in the Kelasu structural belt $[12,48]$. (2) The trap-controlling fault in the northern limb of the Kela-2 structure is the Kashangtuokai thrust fault, which cuts through the $\mathrm{E}_{1-2} \mathrm{~km}$ salt cap rock and reaches the surface (Figure 9). As the Kashangtuokai fault (fault F1) has been consistently active during the Quaternary, it may have been the conduit for vertical leakage of the Kela-2 ancient oil reservoir. Widespread oil and gas shows in the shallow layers of the Kela-2 structure constitute evidence for the upward leakage of oil and gas. Under the influence of movement on fault F1, the Kashangtuokai anticline formed from $3 \mathrm{Ma}$, located $5 \mathrm{~km}$ south of the Kela- 2 gas field. Many oil and gas shows occur at the surface near fault F1 in the Kashangtuokai anticline. Shallow wells drilled into the anticlinal structure, such as wells KDQX1, KDQ1, KDQ2, and KDS1, have variable occurrence of oil and gas, accompanied by high-pressure brine in the Neogene strata (Figure 9). These oil and gas shows provide evidence for leakage from the ancient oil reservoir along fault F1.

The destruction of the ancient Kela- 2 oil reservoir is also recorded by petrographic evidence from the $\mathrm{K}_{1}$ bs sandstone reservoir. Compared with the adjacent Kela-1, Kela-3, and Tubei-1 structures, a very high quantity of authigenic kaolinite is developed in the $\mathrm{K}_{1}$ bs sandstone reservoir in the Kela-2 structure, with an average relative content of $>20 \%$ (Zou et al., 2005b). SEM analysis shows that the kaolinite occurs mainly as flakes and tubular-shaped structures, and is associated predominantly with microquartz and bitumen, being precipitated in intergranular pores (Figures 6(e) and $6(\mathrm{f}))$. K-feldspar and debris dissolution pores are also well developed in the reservoir (Figure 6(d)).

Authigenic kaolinite from the Kela-2 gas field was most likely the product of the late diagenetic stage, for the following reasons. (1) Kaolinite and bitumen were precipitated at the same time, in pores dissolved into feldspar, and in contact with ankerite, which is also dissolved to some extent, indicating that the kaolinite formed later than the ankerite (Figure 6(e)). (2) The $K_{1}$ bs reservoir in the Kela-2 structure is overlapped by thick salt cap rocks and has not been exposed to weathering and erosion after deposition, making it difficult for meteoric water to reach the reservoir. (3) Authigenic kaolinite is not generally developed in the Kelasu thrust belt [49]. During the late stage of diagenesis, the diagenetic environment for the production of authigenic kaolinite requires two main conditions [49-51]: organic acid and $\mathrm{CO}_{2}$ generated by organic matter of the source rock enter the sandstone reservoir; and dissolved matter (especially $\mathrm{K}^{+}$) is able to be discharged. If the fluid discharge is poor, then the dissolution of feldspar and debris will be suppressed [52-54]. That is, the formation of authigenic kaolinite requires an open or semiopen fluid system. It is apparent that the subsalt fluid system of the Kela-2 structure meets the condition of an open or semiopen fluid system for the formation of authigenic kaolinite, for the following reasons. First, the reservoir and the underlying Triassic-Jurassic source rocks are connected by multiple faults that acted as channels for the upward migration of organic acid fluids within the source rocks (Figure 1(b)). Second, subsalt overpressurized fluids migrated along fault F1, which cuts 


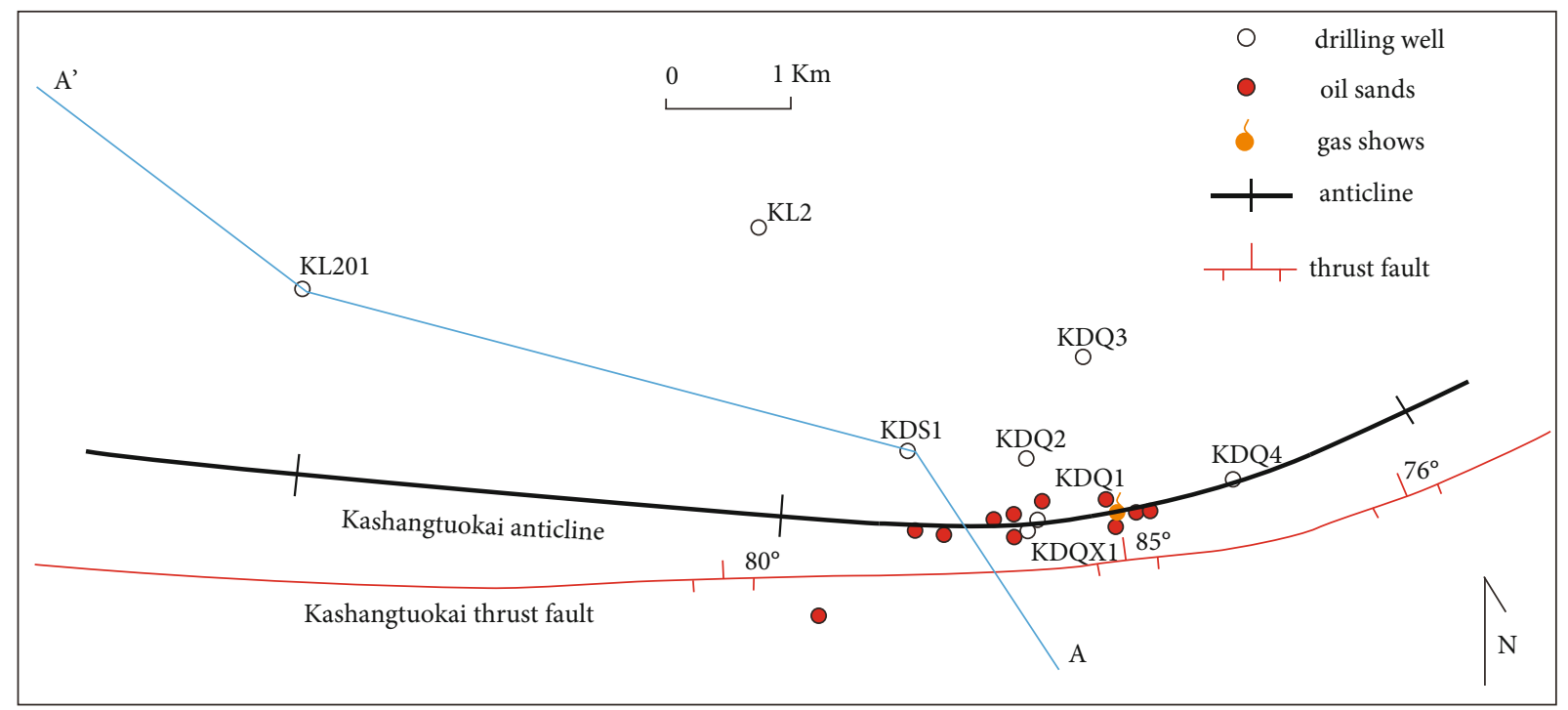

(a)

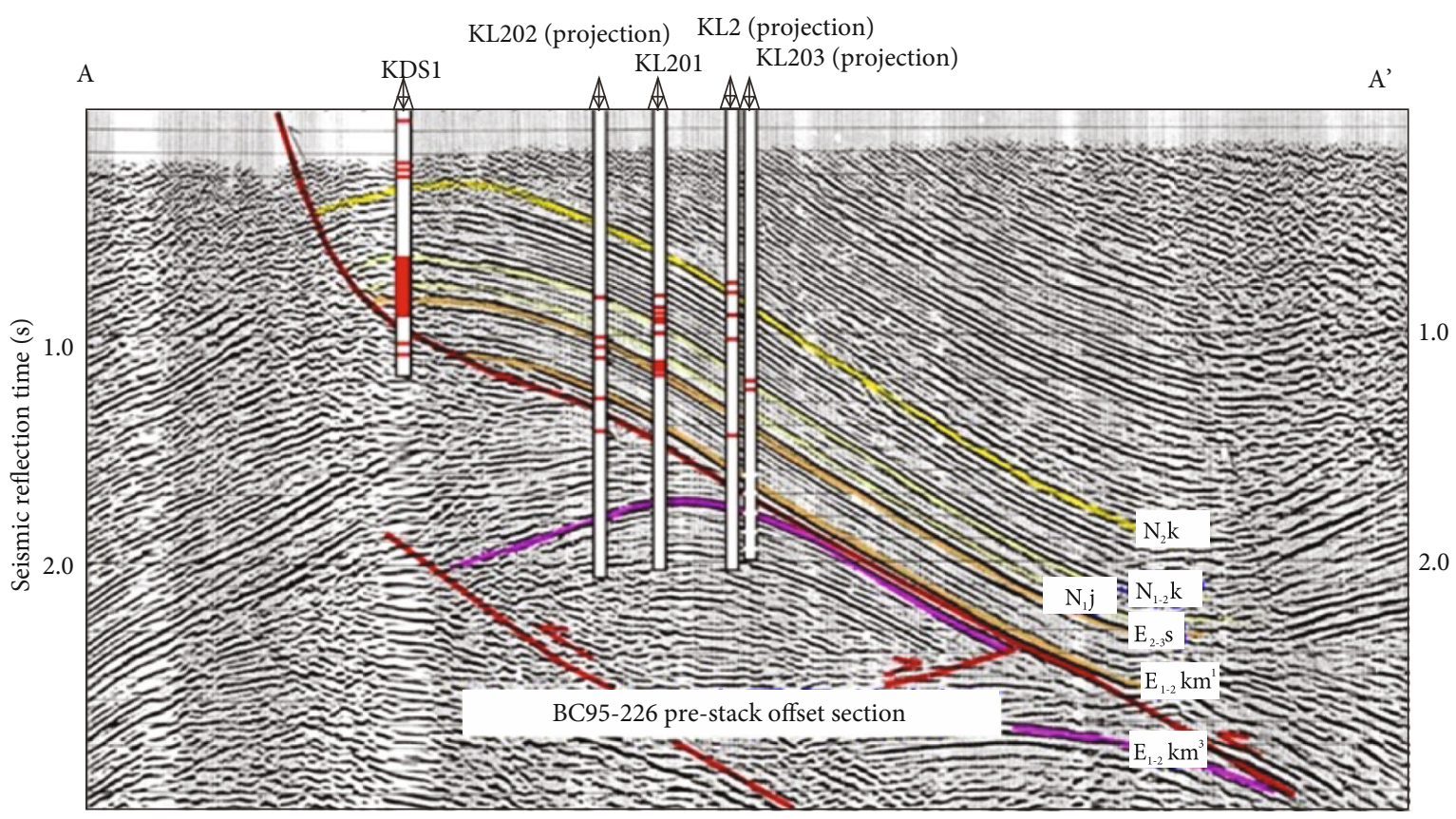

(b)

Figure 9: Surface structure and oil and gas shows in the Kela-2 gas field. (a) Surface geological and structural map of the Kela-2 gas field, showing the Kashangtuokai thrust fault and anticline, and the locations of wells and oil and gas shows. (b) Seismic section showing the structure of Kela-2 and its relationship to the Kashangtuokai thrust fault.

through the salt cap rock and would have resulted in a release of dissolved matter, a reduction in salinity, and the facilitation of dissolution, thereby favoring the formation of kaolinite and secondary pores. A comparison of the very high quantity of authigenic kaolinite in the Kela-2 structure with the lower quantities in the adjacent Kela-1 and Kela-3 structures suggests that fault F1 in the Kela-2 structure was the main conduit for the overpressurized fluid [12] and the locus of fluid leakage in the region [48].

5.4. Movement of the Salt Layer across the Brittle-Ductile Transition and Preservation of Late Charging Gas. After the destruction of the ancient Kela-2 oil reservoir through the activity of fault $\mathrm{F} 1$, the question arises as to how the reservoir was subsequently able to form a large gas field and how fault F1, which cuts through the salt cap rock, did not result in the loss of the late accumulated natural gas. The favored explanation is related to the brittle-ductile behavior of salt rock. According to the results of triaxial compression tests on salt rock, the brittle and ductile responses of this rock are quite different, as brittle deformation occurs mostly under low confining pressure through dilatation and strain localization, with failure finally occurring through the creation of distinct macroscopic shear fractures and faults. In 


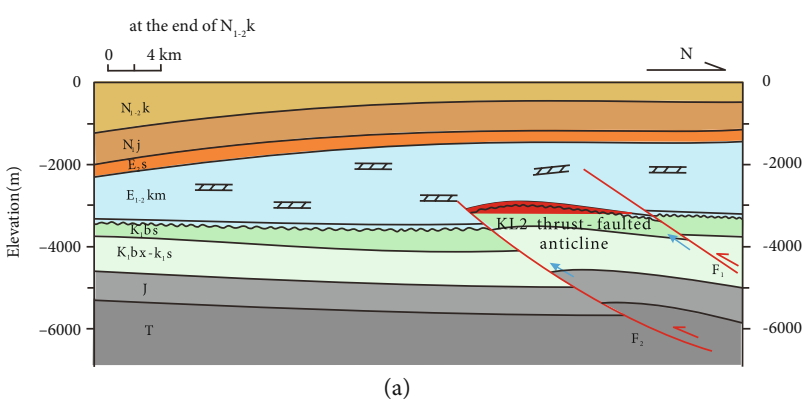

(a)

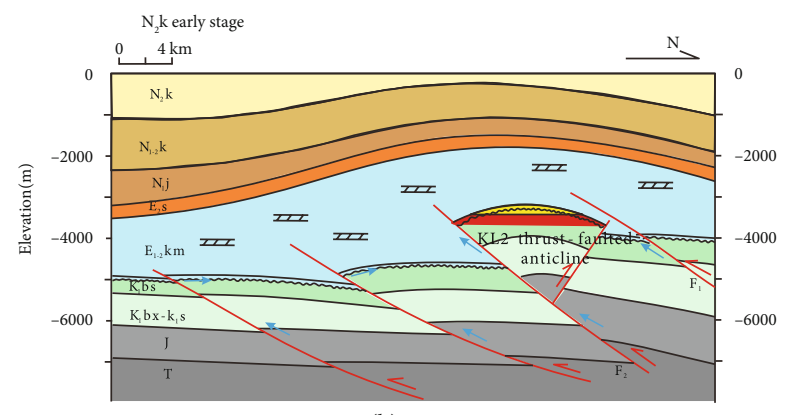

(b)

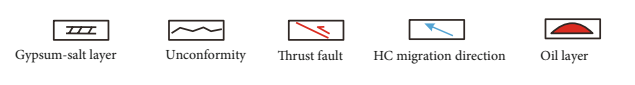

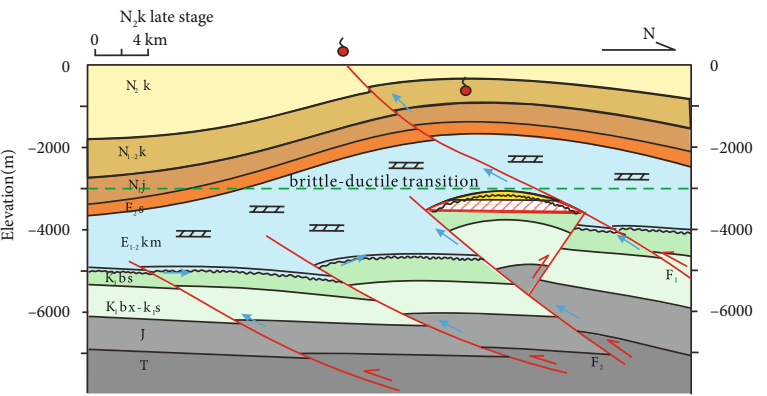

(c)

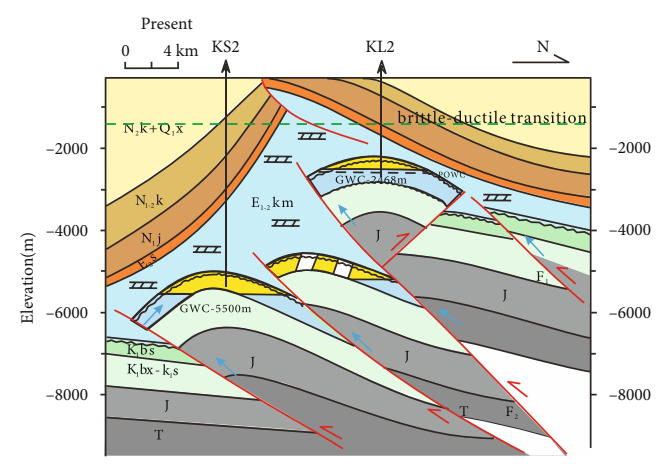

(d)

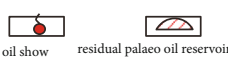

FIgURe 10: Proposed model of dynamic hydrocarbon accumulation in the Kela-2 gas field.

contrast, ductile deformation occurs mostly under high confining pressure and high temperature through contractional and distributed deformation with grain bulging effects [55]. For subsurface rocks, the transition from brittle fracture to plastic flow occurs with increasing depth, higher confining stress, higher temperature, and relatively low strain rate [56]. For the Kela-2 structure and during the early stage of deposition of $\mathrm{N}_{2} \mathrm{k}$, when fault $\mathrm{F} 1$ was formed at about $4 \mathrm{Ma}$, the burial depth of salt caprock was less than $3000 \mathrm{~m}$ (Figure $8(\mathrm{a})$ ). The salt rock was then under conditions of brittle deformation, meaning that fault F1 was able to cut through the salt layer, destroying the integrity of the salt cap rock and resulting in the destruction of the ancient Kela-2 oil reservoir. From $3 \mathrm{Ma}$, the salt rock was under conditions of ductile deformation owing to the increase in burial depth to $>3000 \mathrm{~m}$ (Figure 8(a)). Under intense extrusion during the late stage, the ductile salt rock flowed plastically, and fault F1 was annealed in the salt layer (Figure 7(c)). This process allowed the salt cap rock to become complete again, enabling the formation and preservation of the sub-salt Kela-2 gas field.

5.5. Hydrocarbon Accumulation. During the late Paleogene to early Neogene, the vitrinite reflectance (Ro) value of Triassic lacustrine source rock was $1.3 \%$ to $1.6 \%$, signifying entry to the high-maturity stage, but that of the Jurassic coal-measure source rock was only about $1.0 \%$. Compressional tectonic stress during the early Himalayan period shaped the formation of the Kela-2 faulted anticline (Figure 10(a)). A large volume of mature Triassic oil and gas and a small volume of Jurassic oil migrated upward along Fault F2 and formed the paleo reservoir during the middle Miocene at about $12 \mathrm{Ma}$.

During the period of deposition of unit $\mathrm{N}_{2} \mathrm{k}$, source rocks were buried quickly. The Triassic source rock entered the dry gas generation stage, and the Jurassic coal-measure source rock entered the high-maturity stage and generated large volumes of light oil and gas. The tectonic compressive stress increased, as did the amplitude of the Kela-2 faulted anticline (Figure 10(b)). A large volume of newly generated oil and gas migrated upward along fault F2 into the Kela-2 trap, forming the ancient oil reservoir with an oil-column height of $>350 \mathrm{~m}$. However, at this time, the Keshen- 2 structure had not yet been formed, meaning that an ancient oil reservoir did not exist, thereby explaining the absence of bitumen and oil inclusions in well KS2.

During the late stage of deposition of $\mathrm{N}_{2} \mathrm{k}$ at about $3 \mathrm{Ma}$, fault F1 was reactivated under strong compressional tectonic stress, allowing it to break through the salt caprock which lay within the brittle deformation domain at a depth of $<$ $3000 \mathrm{~m}$. This caused the ancient oil reservoir to leak through fault F1 and be partially destroyed.

After $2 \mathrm{Ma}$, the Jurassic coal-measure source rock entered the overmature stage, generating a large volume of dry gas. At this time, tectonism was weakened, and the trap was gradually stereo-typed, and the salt-cutting fault F1 was annealed owing to the salt rock becoming ductile with increasing depth (Figure 10(d)). The deep and highpressure coal-derived gas generated from the over-mature Jurassic source rock was rapidly charged through the conduit formed by fault F2, generating the current large Kela2 gas field. This charging also exerted a strong gas washing 
and deasphalting effect on the early residual oil [13], leading to the formation of the current dry gas reservoir with little condensate oil and large amounts of residual bitumen in reservoirs. At the same time, the Keshen-2 structure was formed and accumulated gas in its reservoir. The current gas reservoir is composed mainly of overmature gas that accumulated after $2 \mathrm{Ma}$.

\section{Conclusions}

This study used data from analyses of fluid inclusions, petrography, laser Raman spectroscopy, quantitative fluorescence, basin modeling, and hydrocarbon geochemistry, as well as geological evidence and analysis of brittle-ductile deformation of salt rock, to reconstruct the hydrocarbon accumulation history of the Kela-2 gas field in the Kuqa foreland basin, NW China. The following conclusions are drawn.

(1) The Kela-2 gas field was once an ancient oil reservoir with an oil-column height of about $350 \mathrm{~m}$, and the paleo oil-water contact was lower than the present gas-water contact

(2) Under intense thrusting and extrusion from $4 \mathrm{Ma}$, the ancient oil reservoir was destroyed and oil escaped through the salt cap rock through fault F1

(3) With increasing burial depth and higher pressure and temperature over time, the salt cap rock entered the ductile deformation domain, and fault F1 was annealed, allowing intense late gas charging from $2 \mathrm{Ma}$

(4) The Kela-2 gas field has experienced three periods of hydrocarbon charging and one period of adjustment, with the first oil charging at about $12 \mathrm{Ma}$, the second mature oil charging at $4 \mathrm{Ma}$, reservoir destruction by faulting through the salt cap rock at about $3 \mathrm{Ma}$, and the third overmature coal-derived gas charging and preservation from $2 \mathrm{Ma}$

(5) The evolution of the Kela-2 gas field provides an important case study for understanding the role of the brittle-plastic transition of a salt layer and the dynamic evolution of the salt caprock, as well as the process of multiperiod hydrocarbon accumulation and preservation in salt-containing foreland basins

\section{Data Availability}

The data used to support the findings of this study are available from the corresponding author upon request.

\section{Conflicts of Interest}

The authors declare that they have no conflicts of interest.

\section{Acknowledgments}

This work was supported by the National Natural Science Foundation of China (41902045 and 42172164) and the Scientific Research and Technology Development Project of PetroChina (no. 2021DJ0105). These sources of funding are gratefully acknowledged. The help rendered by Professor Li Yong from the Tarim Oilfield Company is greatly appreciated.

\section{References}

[1] C. Z. Jia, D. F. He, and Z. Lei, Oil and Gas Exploration in the Foreland Thrust Belt, Petroleum Industry Press, Beijing (in Chinese), 2000.

[2] C. Z. Jia, X. Y. Zhou, and Z. M. Wang, "Petroleum geology features of Kela 2 gas field," Chinese Science Bulletin, vol. 47, supplement 1, pp. 91-96, 2002.

[3] Z. Wang, T. Wang, Z. Xiao, Z. Xu, M. Li, and F. Lin, "Migration and accumulation of natural gas in Kela-2 gas field," Chinese Science Bulletin, vol. 47, suppl. 1, pp. 107-112, 2002.

[4] Y. X. Zhu, X. J. Shao, and S. Y. Yang, "Character and origin overpressure in Kela-2 gas field," Journal of Southwest Petroleum Institute, vol. 22, no. 4, pp. 9-13, 2000.

[5] D. G. Liang, S. C. Zhang, and J. P. Chen, "Organic geochemistry of oil and gas in the Kuqa depression, Tarim Basin, NW China," Organic Geochemistry, vol. 34, no. 7, pp. 873-888, 2003.

[6] Z. M. Wang and H. S. Long, "Different hydrocarbon accumulation histories in the Kelasu-Yiqikelike structural belt of the Kuqa Foreland basin," Acta Geologica Sinica, vol. 84, no. 5, pp. 1195-1208, 2010.

[7] M. J. Zhao, S. F. Lu, and T. D. Wang, "Natural gas geochemical features and accumulation process in Kela 2 gas field," Chinese Science Bulletin, vol. 47, no. z1, pp. 109-115, 2002.

[8] M. J. Zhao, W. Q. Pan, and S. C. Zhang, "The effects of accumulation process on gas geochemical features in Kela 2 gas field," Earth Science Frontiers, vol. 11, no. 1, p. 304, 2004.

[9] W. Z. Zhao, H. J. Wang, and J. Z. Shan, "Analysis of highly efficient gas reservoir forming process in Kuqa depression," Oil \& Gas Geology, vol. 26, no. 6, pp. 703-710, 2005.

[10] X. X. Zhou, "Recognition on reservoir-forming mechanism of Kela 2 gas field in Tarim Basin," Natural Gas Industry, vol. 14, no. 5, pp. 354-360, 2003.

[11] S. Xu, X. Lu, Z. Sun et al., "Kela-2: a major gas field in the Tarim basin of West China," Petroleum Geoscience, vol. 10, no. 2, pp. 95-106, 2004.

[12] H. Y. Zou, F. Hao, and B. Q. Zhang, "Control of main expelling pathway for overpressure fluid on gas migration and accumulation in Kelasu Thrust Belt of Kuqa depression," Acta Petrolei Sinica, vol. 25, no. 2, pp. 11-20, 2005.

[13] X. Lu, K. Liu, Q. Zhuo, M. Zhao, S. Liu, and S. Fang, "Palaeofluid evidence of the multi-stage hydrocarbon charges in Kela2 gas field, Kuqa foreland basin, Tarim Basin," Petroleum Exploration \& Development, vol. 39, no. 5, pp. 574-582, 2012.

[14] X. Guo, K. Liu, C. Jia, Y. Song, M. Zhao, and X. Lu, "Effects of early petroleum charge and overpressure on reservoir porosity preservation in the giant Kela-2 gas field, Kuqa depression, Tarim Basin, Northwest China," AAPG Bulletin, vol. 100, no. 2, pp. 191-212, 2016. 
[15] Z. Yu, K. Liu, M. Zhao, S. Liu, Q. Zhuo, and X. Lu, "Petrological record of hydrocarbon accumulation in the Kela-2 gas field, Kuqa depression, Tarim Basin," Journal of Natural Gas Science and Engineering, vol. 41, pp. 63-81, 2017.

[16] D. F. He, X. Y. Zhou, and H. J. Yang, "Geological structure and its control on giant oil and gas fields in Kuqa Depression, Tarim Basin: a clue from new shot seisimic data," Geotectonica et Metallogenia, vol. 33, no. 1, pp. 19-32, 2009.

[17] S. Q. Li, X. Wang, and S. John, "Compressional salt tectonics and synkinematic strata of the western Kuqa foreland basin, southern Tianshan, China," Basin Research, vol. 23, pp. 475497, 2012.

[18] J. F. Qi, G. L. Lei, and M. G. Li, "Analysis of structure model and formation mechanism of Kelasu structure zone," Kuqa depression. Geotectonica et Metallogenia, vol. 33, no. 1, pp. 49-56, 2009.

[19] L. J. Tang, C. Z. Jia, Z. J. Jin et al., "Salt tectonic evolution and hydrocarbon accumulation of Kuqa foreland fold belt, Tarim basin, NW China," Journal of Petroleum Science and Engineering, vol. 41, pp. 97-108, 2004.

[20] J. Du, Z. Wang, S. Hu, Q. Wang, and H. Xie, "Formation conditions and geological characteristics of deep giant gas provinces in the Kuqa foreland thrust belt," Petroleum Exploration \& Development, vol. 39, no. 4, pp. 413-422, 2012.

[21] A. C. Aplin, S. R. Larter, M. A. Bigge, G. Macleod, R. E. Swarbrick, and D. Grunberger, "PVTX history of the North Sea's Judy oilfield," Journal of Geochemical Exploration, vol. 69-70, pp. 641-644, 2000.

[22] R. C. Burruss, "Paleotemperatures from fluid inclusions: advances in theory and technique," in Thermal History of Sedimentary Basins: Methods and Case Histories, N. D. Naeser and T. H. McCulloh, Eds., pp. 119-131, Springer-Verlag, New York, 1989.

[23] R. H. Goldstein and T. J. Reynolds, "Systematics of fluid inclusions in diagenetic minerals," SEPM Short Course, vol. 31, p. 199, 1994.

[24] J. Parnell, "Potential of palaeofluid analysis for understanding oil charge history," Geofluids, vol. 10, 82 pages, 2010.

[25] R. E. Swarbrick, "Reservoir diagenesis and hydrocarbon migration under hydrostatic palaeopressure conditions," Clay Minerals, vol. 29, pp. 463-473, 1994.

[26] R. Mclimans, "The application of fluid inclusions to migration of oil and diagenesis in petroleum reservoirs," Applied Geochemistry, vol. 2, no. 5-6, pp. 585-603, 1987.

[27] J. J. Wilkinson, L. Lonergan, and T. Fairs, "Fluid inclusion constraints on conditions and timing of hydrocarbon migration and quartz cementation in Brent Group reservoir sandstones, Columbia Terrace, northern North Sea," in Dating and Duration of Fluid Flow and Fluid-Rock Interaction, J. Parnell, Ed., vol. 144, pp. 69-89, Geological Society Special Publication, New York, 1998.

[28] B. H. Hartmann, K. Juhasz-Bodnar, and K. Ramseyer, "Polyphased quartz cementation and its sources: a case study from the upper Paleozoic Haushi group sandstones, Sultanate of Oman," in Quartz Cementation in Sandstones, R. H. Worden and S. Morad, Eds., vol. 29, pp. 253-270, International Association of Sedimentologists Special Publication, New York, 2000.

[29] T. Nedkvitne, D. A. Karlsen, K. Bjørlykke et al., "Relationship between reservoir diagenetic evolution and petroleum emplacement in the Ula Field, North Sea," Marine and Petroleum Geology, vol. 10, pp. 255-270, 1993.
[30] K. Y. Liu and P. Eadington, "Quantitative fluorescence techniques for detecting residual oils and reconstructing hydrocarbon charge history," Organic Geochemistry, vol. 36, no. 7, pp. 1023-1036, 2005.

[31] K. Liu, X. Pang, Z. Jiang, and P. Eadington, "Quantitative estimate of residual or palaeo-oil column height," Journal of Geochemical Exploration, vol. 89, no. 1-3, pp. 239-242, 2006.

[32] K. Liu, P. Eadington, H. Middleton, S. Fenton, and T. Cable, "Applying quantitative fluorescence techniques to investigate petroleum charge history of sedimentary basins in Australia and Papuan New Guinea," Journal of Petroleum Science and Engineering, vol. 57, no. 1-2, pp. 139-151, 2007.

[33] K. Liu, S. C. George, X. Lu, S. Gong, H. Tian, and L. Gui, “Innovative fluorescence spectroscopic techniques for rapidly characterising oil inclusions," Organic Geochemistry, vol. 72, 2014.

[34] J. S. Hanor, "Dissolved methane in sedimentary brines: potential effect on the PVT properties of fluid inclusions," Economic Geology, vol. 75, no. 4, pp. 603-609, 1980.

[35] R. Thiéry, J. Pironon, and F. Walgenwitz, "Individual characterization of petroleum fluid inclusions (composition and _ $\mathrm{P}_{-}$- _ $\mathrm{T}_{-}$trapping conditions) by microthermometry and confocal laser scanning microscopy: inferences from applied thermodynamics of oils," Marine Geology, vol. 19, no. 7, pp. 847-859, 2002.

[36] R. H. Goldstein, "Fluid inclusions in sedimentary and diagenetic systems," Lithos, vol. 55, pp. 159-193, 2001.

[37] X. Guo, K. Liu, C. Jia et al., "Constraining tectonic compression processes by reservoir pressure evolution: overpressure generation and evolution in the Kelasu thrust belt of Kuqa foreland basin, NW China," Marine and Petroleum Geology, vol. 72, pp. 30-44, 2016.

[38] Q. G. Zhuo, M. J. Zhao, Y. Li, and Y. Wang, "Dynamic sealing evolution and hydrocarbon accumulation of evaporate cap rocks: an example from Kuqa depression foreland thrust belt," Acta Petrolei Sinica, vol. 35, no. 5, pp. 1-10, 2014.

[39] Q. G. Zhuo, F. W. Meng, Y. Song, H. J. Yang, Y. Li, and P. Ni, "Hydrocarbon migration through salt: evidence from Kelasu tectonic zone of Kuqa foreland basin in China," Carbonates and Evaporites, vol. 29, pp. 291-297, 2014.

[40] P. J. Hamilton, S. Kelly, and A. E. Fallick, "K-Ar dating of illite in hydrocarbon reservoirs," Clay Minerals, vol. 24, no. 2, pp. 215-231, 1989.

[41] Y. Y. Zhang, H. Zwingwann, and A. Todd, "K-Ar dating of authigenic illite and its applications to study of oil-gas charging histories of typical sandstone reservoirs, Tarim basin," Earth science Frontiers, vol. 11, no. 4, pp. 637-647, 2004.

[42] Z. Jiang, L. Li, Y. Song et al., "Control of neotectonic movement on hydrocarbon accumulation in the Kuqa foreland basin, West China," Petroleum Science, vol. 7, no. 1, pp. 49$58,2010$.

[43] L. B. Zeng, T. W. Zhou, and X. X. Lu, "Influence of Himalayan orogeny on oil \& gas forming in Kuqa depression, Tarim basin," Earth Scicence-Journal of China University of Geosciences, vol. 27, no. 6, pp. 741-744, 2002.

[44] L. Zeng, H. Wang, L. Gong, and B. Liu, "Impacts of the tectonic stress field on natural gas migration and accumulation: a case study of the Kuqa Depression in the Tarim Basin, China," Marine and Petroleum Geology, vol. 27, no. 7, pp. 1616-1627, 2010.

[45] Q. G. Zhuo, M. J. Zhao, and H. W. Xie, "Relationship between reservoir bitumen and hydrocarbon migration in Dabei 
region, Kuqa foreland basin," Petroleum Geology \& Experiment, vol. 33, no. 2, pp. 193-196, 2011.

[46] B. Horsfield, H. J. Schenk, N. Mills, and D. H. Welte, “An investigation of the in-reservoir conversion of oil to gas: compositional and kinetic findings from closed-system programmed-temperature pyrolysis," Organic Geochemistry, vol. 19, no. 1-3, pp. 191-204, 1992.

[47] Q. G. Zhuo, Y. Li, and X. S. Lu, "Condensate characteristics and its significance for hydrocarbon accumulation in the Kelasu structural belt," Natural Gas Geoscience, vol. 23, no. 6, pp. 1097-1103, 2012.

[48] X. J. Pi, H. W. Xie, and C. Zhang, "Overpressure mechanism and its control on reservoir formation in Kuqa foreland thrust belt," Chinese Science Bulletin, vol. 47, suppl. 1, pp. 84-90, 2002.

[49] H. Y. Zou, F. Hao, G. D. Liu, and C. Sui, "Genesis of authigenic kaolinite and gas accumulation in Bashijiqike Fm sandstone in Kuqa thrust belt," Oil \& Gas Geology, vol. 26, no. 6, pp. 786791, 2005.

[50] R. C. Surdam, S. W. Boese, and L. J. Crossey, "The chemistry of secondary porosity," Clastic Diagenesis American Association of Petroleum Geologists Memoir, D. A. McDonald and R. C. Surdam, Eds., vol. 37, pp. 127-149, 1984.

[51] I. Van Keer, P. H. Muchez, and W. Viaene, "Clay mineralogical variations and evolutions in sandstone sequences near a coal seam and shales in the Westphalian of the Campine Basin (NE Belgium)," Clay Minerals, vol. 33, no. 1, pp. 159-169, 1998.

[52] M. R. Giles and R. B. de Boer, "Origin and significance of redistributional secondary porosity," Marine and Petroleum Geology, vol. 7, no. 4, pp. 378-397, 1990.

[53] S. Morad, J. M. Ketzer, and F. De Ros, "Spatial and temporal distribution of diagenetic alterations in siliciclastic rocks: implications for mass transfer in sedimentary basins," Sedimentology, vol. 47, Supplement 1, pp. 95-120, 2000.

[54] G. C. Saigal, K. Sjorlykke, and S. Larter, "The effect of oil emplacement on diagenetic processes: examples from the Fulmar reservoir sandstones," Central North Sea. AAPG Bull., vol. 76, no. 7, pp. 1024-1033, 1992.

[55] S. Muhuri, T. Scott Jr., and D. Stearns, Microfracutring in the Brittle-Ductile Transition in Berea Sandstone, In: 4th North American Rock Mechanics Symposium, American Rock Mechanics Association, 2000.

[56] B. Evans, J. T. Fredrich, and T. F. Wong, "The brittle-ductile transition in rocks: recent experimental and theoretical progress," The Brittle-Ductile Transition in Rocks, Geophysical Monograph, vol. 56, pp. 1-20, 1990. 